\title{
4. PLANKTONIC FORAMINIFERAL BIOSTRATIGRAPHY AND PALEOCEANOGRAPHY OF LATE QUATERNARY TURBIDITE SEQUENCES AT HOLES 856A, 857A, AND 857C, LEG 1391
}

\author{
Charlotte A. Brunner ${ }^{2}$
}

\begin{abstract}
Late Quaternary planktonic foraminiferal biostratigraphy and paleoceanography were examined at two sites from the east margin of Middle Valley of the northern Juan de Fuca Ridge. Calcareous microfossils are abundant and well preserved in the upper sequences where thermal and hydrothermal alteration is minimal and where deposition occurred after sites were tectonically raised above the turbidite plain of the axial valley. Approximately 200 samples were examined to determine depositional style and foraminiferal content including a census of planktonic foraminifers. Approximately $60 \%$ of the samples contain turbiditic material, so paleontologic interpretations must be made with caution.

Ocean Drilling Program (ODP) Holes 856A and 857A contain abundant foraminifers above 52 and $85 \mathrm{mbsf}$, respectively. The fossiliferous sequences are divided into four informal coiling direction zones based on the species Neogloboquadrina pachyderma (Ehrenberg) and numbered from 1 to 4 from top to bottom of the sequences. Coiling direction zones 1 and 3 contain $<90 \%$ sinistral forms and include the lower part of the present and penultimate interglacial periods and perhaps part of the glacial termination. Coiling direction zones 2 and 4 contain $>90 \%$ sinistral forms and span most of the last two glacial periods. The bases of coiling direction zones 1 and 3 define two datum levels tentatively dated at 11,000 and $125,000 \mathrm{yr}$ ago, respectively.

Cluster analysis identified three assemblages: a subarctic assemblage, a transitional assemblage, and a subarctic dissolution assemblage. The subarctic dissolution assemblage occurs infrequently and sporadically throughout the unaltered glacial intervals in Holes $856 \mathrm{~A}$ and $857 \mathrm{~A}$. In contrast, the dissolution assemblage dominates Hole $856 \mathrm{~A}$ below $22 \mathrm{mbsf}$ and is related to calcite precipitation driven by hydrothermal processes. The transitional assemblage appears in coiling direction zone 3 and records the close approach of the subpolar boundary to the ODP Leg 139 locale during the penultimate interglacial period. The subpolar boundary remained south of the study site at approximately $48^{\circ} 30^{\prime} \mathrm{N}$ latitude throughout the late Quaternary.
\end{abstract}

\section{INTRODUCTION}

The nominal objectives of this work are to determine the biostratigraphy and paleoenvironmental history at two Ocean Drilling Program (ODP) Leg 139 sites. The Leg 139 locality presents several obstacles to these goals. The sites are probably Quaternary in age because they lie above Brunhes Chron basement. At present, relatively little is known about Quaternary climatic events of the northeast Pacific Ocean (compared to our knowledge of the North Atlantic Ocean, for example) and Quaternary biostratigraphy is inadequately resolved in the region (see "Biostratigraphy of the Northeast Pacific Ocean" section, this chapter). The locality lies in Middle Valley, a spreading center of the Juan de Fuca Ridge, so hydrothermal and thermal alteration play a role in fossil preservation. The valley is thickly sedimented by about a kilometer of turbidites shed from the glaciated margin of British Columbia, and sedimentation rates exceed $190 \mathrm{~cm} /$ k.y. (Davis, Mottl, Fisher, et al., 1992, p. 304). The high sedimentation rates produce expanded sequences of Quaternary calcareous fossils in hemipelagic intervals, especially since the locality lies.mostly above the regional calcium carbonate compensation depth (CCD) during both glacial and interglacial periods. However, the turbidites also dilute sediments, disrupt trends, and in other ways disturb the sequences.

The effort calls attention to several biostratigraphic and paleoenvironmental issues of wider significance. We do not know at this time if foraminiferal faunas and the water masses they reflect change significantly in the subarctic northeast Pacific during glacial-interglacial cycles or if assemblage change is restricted to the southerly

\footnotetext{
${ }^{1}$ Mottl, M.J., Davis, E.E., Fisher, A.T., and Slack, J.F. (Eds.), 1994. Proc. ODP, Sci. Results, 139: College Station, TX (Ocean Drilling Program).

${ }^{2}$ Center for Marine Science, University of Southern Mississippi, Stennis Space Center, MS 39529, U.S.A.
}

portions of the region. Does the transitional fauna invade the study region during interglacial periods, or is the fauna uniformly subarctic in character throughout the Brunhes? Does the preserved fauna record changes in upwelling, dilution of surface waters, and/or migration of water masses across the study region? Planktonic foraminiferal assemblage zones of the subarctic are poorly defined in the Brunhes. Calcium carbonate and oxygen isotopic stratigraphies suggest that there are six or seven warmings during the Brunhes. Do interglacial planktonic foraminiferal assemblages appear below the present interglacial interval? Do interglacial intervals correspond to carbonaterich intervals? This exploratory work makes progress toward answering aspects of these questions.

\section{Biostratigraphy of the Northeast Pacific Ocean}

Assemblage zones must be used to subdivide the transitional and subarctic North Pacific Ocean during the Pleistocene because there are few evolutionary events among the cold-water planktonic foraminifers during this interval (Lagoe and Thompson, 1988). The simplest type of assemblage zone, the coiling direction zone, has been used to great effect in the transitional water mass and the California Current. Specifically, Pleistocene warm/cold cycles and coiling direction zones have been described using the relative proportions of sinistral and dextral $\mathrm{Nq}$. pachyderma.

Placement of the Holocene-Pleistocene boundary in the northeast Pacific Ocean is in question. In the California Borderland, Bandy (1960) recognized a dextral interval in recent sediments underlain by a sinistral interval. The coiling shift between the zones occurred approximately $11,000 \mathrm{yr}$ ago and is widely used to mark the regional Holocene-Pleistocene boundary. More recent work from offshore northern California (Brunner and Ledbetter, 1989; Gardner et al., 1988) shows that a dextral to sinistral couplet lies immediately below the Holocene dextral zone. The base of the dextral interval is dated at about $15,000 \mathrm{yr}$ ago; the sinistral event occurred about $11,500 \mathrm{yr}$ ago (Gardner et al., 1988). The late Holocene is dominated by sinistral $N q$. 
pachyderma that may mark the onset of coastal upwelling in the California Current (Karlin et al., 1992).

The lower and middle Pleistocene is subdivided by the coiling zones of Lagoe and Thompson (1988), who defined nine zones (CD8 to CD16) between 0.6 and $4 \mathrm{Ma}$. Coiling zones are fairly well defined below 1.2 Ma because coiling shifts are relatively infrequent and boundaries are constrained by a number of evolutionary events. However, coiling zones remain poorly defined between the latest Pleistocene and the CD9/CD10 boundary at about $1.2 \mathrm{Ma}$.

Coiling dominance has shifted frequently throughout most of the Pleistocene. In general, the lower Pleistocene sequences contain cool and cold assemblages in alternation (Lagoe and Thompson, 1988; Kent et al., 1971), whereas the upper Pleistocene sequences contain a cold assemblage punctuated by a number of short warm intervals. Two extinction events before 0.6 Ma provide some time control for the lower Pleistocene, but no such events occur in the upper Pleistocene (Lagoe and Thompson, 1988), making unique identification of coiling intervals difficult. At present, the geographic extent and number of migrations of dextral $N q$. pachyderma into the subarctic is unknown, but oxygen isotopic and carbonate stratigraphy suggest that it is reasonable to look for six migrations (Zahn et al., 1991) corresponding to oxygen isotopic stage terminations (Brunner and Ledbetter, 1989; Gardner et al., 1988) 1-2, 5-6, 7-8, 11-12, 13-14, and 15-16.

\section{Pleistocene Paleoenvironmental History}

The lower Pleistocene of the North Pacific Ocean was a period of relative warmth dominated by dextral Neogloboquadrina pachyderma (Olsson and Goll, 1970; Kent et al., 1971; Ingle, 1973a,b; Lagoe and Thompson, 1988). The climatic warmth extended into the subarctic Pacific Ocean as indicated by the presence of dextral Nq. pachyderma in subpolar waters (Kent et al., 1971). Sinistral Nq. pachyderma increased abruptly relative to its dextral form after $1.2 \mathrm{Ma}$, indicating a pronounced cooling throughout the region (Ingle, 1973a; Kent et al., 1971). Thompson (1980) suggests that the dextral morph has been environmentally excluded from the subarctic Pacific Ocean since this major cooling.

The North Pacific has undergone a number of climatic cycles since the cooling 1.2 Ma. Lagoe and Thompson (1988) describe conditions that fluctuate between cold and cool from 1.2 to $0.6 \mathrm{Ma}$. After $0.6 \mathrm{Ma}$ conditions appear generally cold, but are punctuated by an uncertain number of warm events above the Brunhes-Matuyama boundary $(0.73 \mathrm{Ma})$. Most data come from regions south of the subarctic front. Thompson (1980) identifies six southerly invasions of sinistral $\mathrm{Nq}$. pachyderma in the Brunhes Magnetozone in the Japan Trench region that correspond to oxygen isotopic stages 2, 4, 6, 8, 12, and 16, and Kheradyar (1992) shows six or seven northerly invasions of dextral $N q$. pachyderma into the southernmost Japan Sea.

Carbonate stratigraphy supplies some clues to the number of climatic cycles in the Brunhes Magnetozone. In the subarctic northwestern Pacific Ocean, Kent et al. (1971) observed six carbonate-rich intervals interspersed with barren intervals above the Brunhes-Matuyama boundary in core V20-119. The fossiliferous intervals all contain sinistral $\mathrm{Nq}$. pachyderma and were deposited during interglacial periods based on oxygen isotopic ratios (Hays and Shackleton, 1976; Thompson and Shackleton, 1980). The barren intervals apparently correspond to glacial periods in contrast to the general pattern of carbonate preservation in the Pacific Ocean. The preceding results support the suggestion that dextral $\mathrm{Nq}$. pachyderma does not penetrate the northwestern subarctic Pacific Ocean even during interglacial periods. The opposite preservation pattern occurs in the subarctic northeast Pacific. Six carbonate-rich intervals were deposited during the Brunhes (Zahn et al., 1991; Karlin et al., 1992; Nayudu, 1964), and they correspond to oxygen isotopic stages $2-3,6,8,12,14$, and 16 (Zahn et al., 1991; Karlin et al., 1992). Coiling curves are not yet available for this suite of cores.

\section{Environmental Setting}

\section{Hydrography and Paleohydrography}

Surface waters of the subarctic North Pacific Ocean in general are characterized by low temperature and salinity less than $34 \%$. Subarctic waters are clearly separated from subtropical waters by a strong oceanic front where the $3^{\circ} \mathrm{C}$ isotherm plunges from $100 \mathrm{~m}$ north of the boundary to $1000 \mathrm{~m}$ south of the boundary, which lies between $40^{\circ}$ and $45^{\circ} \mathrm{N}$ latitude. Distinctive surface water masses are produced in subarctic waters by the interaction of several processes: winter overturn, which produces a subsurface temperature minimum; dilution from spring and summer meltwaters that spread from the coasts; divergence and upwelling in gyre centers; coastal upwelling; and seasonal ice cover in regions adjacent to the subarctic ocean, such as the Sea of Okhotsk.

Favorite et al. (1976) divide surface waters (upper $300 \mathrm{~m}$ ) into five domains of distinctive hydrographic characteristics separated by current systems. Leg 139 sites lie at the eastern extreme of the Subarctic Current System where the continent diverts flow to the north as the Alaska Current and to the south as the California Current (Sverdrup et al., 1942), between the Dilute Domain and the Upwelling Domain of the coast (Favorite et al., 1976). Salinities of the Dilute Domain at $50 \mathrm{~m}$ and deeper are reduced by spring and summer plumes from the Columbia River, the Strait of Juan de Fuca, Queen Charlotte Sound, and Dixon Entrance and are surrounded by higher salinities brought near the surface by divergence in the surrounding regions. The Upwelling Domain near the study region is active from late spring to early fall. It undergoes seasonal reversal of coastal flow (Davidson and California Currents) and seasonal discharge from the Columbia River. Mean surface temperature in summer is more than $5^{\circ} \mathrm{C}$ lower, and mean salinities are $0.1 \%$ to $0.3 \%$ higher in the Upwelling Domain than in the Dilute Domain. Both domains are distinctively different from the Transition Domain, which lies between them and the Subarctic Boundary. The hydrographic boundaries are reflected in the biogeography of plankton (Bradshaw, 1959). A subarctic fauna lives at the study site and a transitional fauna is found to the south in the Transition Domain.

Conditions during the last glacial maximum 18,000 yr ago were quite different. The Subarctic Boundary lay about $5^{\circ}$ south of its present position in the western and central portions of the North Pacific Ocean (Thompson, 1981) and subpolar waters extended down the California coast (Moore et al., 1980). The western and central subarctic were more affected by seasonal ice cover and were similar to the present-day Sea of Okhotsk (Sancetta, 1979). Coastal upwelling offshore from Oregon was greatly reduced and did not return to presentday conditions until $7000 \mathrm{yr}$ ago (Karlin et al., 1992; Lyle et al., 1992). Summer surface-water temperature was $2^{\circ} \mathrm{C}$ cooler and winter surface-water temperature was $4^{\circ} \mathrm{C}$ cooler than present-day temperatures (Moore et al., 1980) in the study region.

The CCD depth lies between 2200 and $2700 \mathrm{~m}$ at present based on the percentage of carbonate in core-top sediments (Karlin et al., 1992) and near $2700 \mathrm{~m}$ based on preservation of subarctic core-top faunas (Coulbourn et al., 1980). In contrast, the CCD migrates to depths between 4400 and $4500 \mathrm{~m}$ in the region during Pleistocene glaciations (Karlin et al., 1992). Sites 856 and 857 lie at 2395 and $2418 \mathrm{~m}$ water depth, near or above the interglacial upper limit of the CCD. I expect that carbonate fossils will be preserved even during interglacial periods when carbonate preservation in the Pacific Ocean is generally poor (Berger, 1976).

\section{Planktonic Foraminiferal Fauna}

Bradshaw (1959) reported that living faunas of planktonic foraminifers have biogeographical distributions that generally follow the outlines of the major water masses (Sverdrup et al., 1942). Middle 
Valley (near $48^{\circ} 30^{\prime} \mathrm{N}, 128^{\circ} 45^{\prime} \mathrm{W}$ ) lies near the boundary between the subarctic fauna and the transitional fauna (Bradshaw, 1959), but Bradshaw (1959) was not able to locate the boundary because his samples do not extend into the northeast subarctic. Species found in sediment traps in subarctic waters nearby $\left(50^{\circ} \mathrm{N}, 145^{\circ} \mathrm{W}\right)$ include Turborotalita quinqueloba (Natland), sinistral and dextral Nq. pachyderma (Ehrenberg), Globigerina bulloides d'Orbigny, Orbulina universa d'Orbigny, Globigerinita glutinata (Egger), and Globorotalia scitula (Brady) (Reynolds and Thunell, 1985; Reynolds and Thunell, 1986; Sautter and Thunell, 1989). Bradshaw (1959) also reported small Neogloboquadrina dutertrei and a form similar to Globigerinita minuta (Natland) in his plankton net samples. The transitional fauna of Bradshaw (1959) contains Globigerina bulloides, large Neogloboquadrina dutertrei, Turborotalita quinqueloba, Orbulina universa, and Globigerinoides ruber and includes a mix of species from neighboring faunas near its boundaries. The central-water assemblage to the south of the transitional fauna is marked by Globorotalia inflata and Globorotalia truncatulinoides (Bradshaw, 1959).

The distribution of planktonic faunas is mirrored by fossil assemblages in surficial sediment. Coulbourn et al. (1980) found that sinistral $\mathrm{Nq}$. pachyderma dominates the fossil assemblage beneath the subarctic fauna of Bradshaw (1959), dextral Nq. pachyderma dominates the fossil assemblage beneath the transitional fauna, and Globorotalia inflata flags sediments beneath the central-water assemblage. Dissolution on the seafloor modifies planktonic foraminiferal assemblages by removing delicate species. For example, the subarctic fossil fauna becomes enriched in sinistral $\mathrm{Nq}$. pachyderma at the expense of solution susceptible species of the subarctic fauna (Sautter and Thunell, 1989; Coulbourn et al., 1980; Berger, 1981).

\section{Geologic Setting of Middle Valley}

Sequences at Middle Valley are dominated by turbidite deposition into the rift. The rift valley is a bathymetric low that acts as a depositional trap for turbidites originating on the continental slope of Vancouver Island and Queen Charlotte Sound. Deposition was probably accelerated during low stands of the sea when alpine and continental glaciers added large amounts of debris to the continental slope.

The Leg 139 sites are located near the eastern wall of the valley. Hole $856 \mathrm{~A}$ is located at the crest $(2395 \mathrm{~m})$ of a small hill that stands about $60 \mathrm{~m}$ above the surrounding turbidite plain. The southern flank of the hill is associated with several sulfide mounds. The hole terminates at a mafic sill intruded at 115 mbsf within the sediment pile, which was somewhat altered during intrusion and cooling of the sill. Site 856 lies on crust that could be as old as $320,000 \mathrm{yr}$ based on its distance from the east edge of the Brunhes magnetic chron.

Site 857 sits on a block that has been uplifted a few tens of meters above and tilted eastward from the turbidite plain of the valley axis. Sediments at this locality are thick, consisting of $470 \mathrm{~m}$ of turbidites and an additional $457 \mathrm{~m}$ of interbedded sills and sediments. Heat flow is high at the site, which lies between a large hydrothermal vent field and the presumed fluid recharge area at the eastern faulted rim of the valley. Age of basement is about $250,000 \mathrm{yr}$ old based on spreading rates.

\section{METHODS}

The sequences at Middle Valley consist mostly of silt- and sandbased turbidites interspersed with unsorted silty clays and clayey silts which could be turbiditic or hemipelagic. Most foraminiferal samples were selected from the unsorted silt and clay units to minimize sampling of sorted and displaced faunas. Core photos were used to verify the lithology of each sample because most samples were not taken personally by the author. All samples span 2 to $3 \mathrm{~cm}$ of depth in core, and so potentially average together fine-scale depositional units characteristic of silt-based turbidites (Stow and Piper, 1984; Brunner and Ledbetter, 1987, 1989).
Samples were prepared for planktonic foraminifers using conventional micropaleontologic techniques. Samples were oven-dried at $50^{\circ} \mathrm{C}$, weighed, soaked in a $1 \%$ Calgon solution for $1 \mathrm{hr}$, and washed in a sieve with $63-\mu \mathrm{m}$ openings. Samples washed on board the Resolution, however, were not weighed. The sand-size residue was ovendried at $50^{\circ} \mathrm{C}$ and inspected microscopically to identify and rank qualitative abundance of the constituents. The sand content ( $\%$ by weight) of all weighed samples was calculated.

The depth of the Holocene-Pleistocene boundary (Bandy, 1960) was determined in Holes $855 \mathrm{~A}, 855 \mathrm{C}, 856 \mathrm{~A}, 856 \mathrm{~B}, 857 \mathrm{~A}, 857 \mathrm{~B}$, $857 \mathrm{C}, 858 \mathrm{~A}, 858 \mathrm{C}$, and $858 \mathrm{D}$ using the coiling ratio of $\mathrm{Nq}$. pachyderma. A minimum of 30 specimens was inspected for coiling direction to calculate the relative frequency of sinistral forms (number of sinistral forms/[number of sinistral + number of dextral forms]). The minimum of 30 specimens has a probable error greater than $15 \%$ for relative frequencies less than $40 \%$. (Krumbein and Pettijohn, 1938, fig. 245). The sensitivity is sufficient for detection of potential interglacial samples that have sinistral frequencies less than $90 \%$.

Holes 856A, 857A, and $857 \mathrm{C}$ were selected for assessment of Pleistocene planktonic foraminiferal biostratigraphy and paleoenvironment. Samples selected from Hole 857C (115.46 to $389.7 \mathrm{mbsf}$ ) underlie those at $857 \mathrm{~A}$ ( 0 to $108.38 \mathrm{mbs}$ ). The three holes were chosen because foraminifers are preserved to great depth and two of the holes ( $856 \mathrm{~A}$ and $857 \mathrm{~A})$ were hydraulically piston-cored ensuring minimal coring disturbance. A census of species was made in all 103 samples in which a minimum of 300 planktonic foraminifers was found. The samples were split using a modified Otto microsplitter when necessary. The number of benthic foraminifers was also noted during the census. Several terms were calculated from these data including (1) the benthic foraminiferal frequency $(100$ - number of benthic foraminifers/[number of benthic + number of planktonic foraminifers]), (2) the planktonic foraminiferal number (number of planktonic foraminifers/[fraction of sample counted] [dry sediment weight]), (3) the coiling ratio of Nq. pachyderma $(100 \cdot$ sinistral forms/[sinistral + dextral forms]), and (4) the relative frequency of common planktonic foraminiferal species (see "Taxonomic Notes" section, this chapter).

Cluster analysis was used to group together samples with the most similar species composition (Q-mode). The analysis agglomerated unweighted samples with the simple Euclidean distance coefficient using the average linkage (within group) method. Several other methods of agglomeration were tried and produced similar basic groupings indicating that the basic groupings were fairly stable. Several samples, however, were joined to different groups depending on the agglomeration method. These samples apparently lie at the boundaries of the clusters and are intermediate in their species composition. The clustering effort succeeds in defining basic groupings and is not intended to optimally group every sample. The validity of the sample clusters, which are based on similarity of species composition, was corroborated by calculating Pearson correlation coefficients between pairs of species to demonstrate the strength of their associations.

\section{RESULTS \\ Lithology}

Many samples contain at least some sediment that is turbiditic in origin. Sample intervals were examined from the core photos to determine lithology (Tables 1 and 2). Two samples were taken from the disturbed soft mud or sand between hard "biscuits" formed during drilling of semi-indurated sediments. These samples are likely contaminated with material slumped down the hole. Two samples were taken in well-sorted silt layers and are wholly turbiditic. Many samples (30) contain a thin layer (of millimeters) or blebs of well-sorted silt amid mostly muddy material, so the samples contain at least some turbiditic material which may be mixed with hemipelagic sediment. Some samples (43) are from the muddy tops of fining upward sequences. The muds may be hemipelagic, turbiditic, or a bioturbated 


\section{C.A. BRUNNER}

Table 1. Constituents of the sand-size fraction, Hole 856A.

\begin{tabular}{|c|c|c|c|c|c|c|c|}
\hline $\begin{array}{l}\text { Core, section, } \\
\text { interval }(\mathrm{cm})\end{array}$ & $\begin{array}{l}\text { Depth } \\
\text { (mbsf) }\end{array}$ & Sand & Fno & $\mathrm{B} / \mathrm{P}$ & Coil & Lith & Constituents of the sand-size fraction \\
\hline \multicolumn{8}{|l|}{$139-856 \mathrm{~A}-$} \\
\hline $1 \mathrm{H}-1,0-1$ & 0.00 & & & 57 & 85 & Mud & Clay lumps, radiolarians, diatoms, foraminifers \\
\hline $1 \mathrm{H}-1,91-93$ & 0.91 & 1.5 & 8160 & 2 & 97 & Mud & Forams, pyrite \\
\hline $1 \mathrm{H}-2,48-50$ & 1.98 & 1.8 & 4998 & 2 & 97 & Mud & Forams, pyrite \\
\hline $2 \mathrm{H}-2,90-92$ & 5.10 & 0.3 & 167 & 29 & 99 & Mud & Forams, pyrite, radiolarians \\
\hline $2 \mathrm{H}-3,90-92$ & 6.60 & 0.1 & 22 & 7 & 98 & Top fus & Pyrite, mineral grains, forams \\
\hline $2 \mathrm{H}-4,101-103$ & 8.21 & 0.4 & 339 & 18 & 99 & Mud & Forams, pyrite, mineral grains \\
\hline $2 \mathrm{H}-5,86-88$ & 9.56 & 0.3 & 131 & 48 & 97 & Top fus & Pyrite, forams \\
\hline $2 \mathrm{H}-6,86-88$ & 11.06 & 0.6 & 1133 & 5 & 98 & Top fus & Forams, pyrite, mineral grains, radiolarians \\
\hline $2 \mathrm{H}-7,56-58$ & 12.26 & 0.8 & 1928 & 1 & 98 & Mud & Forams, pyrite, mineral grains \\
\hline $3 \mathrm{H}-3,72-74$ & 15.92 & 0.2 & 185 & 9 & 100 & Top fus & Forams, pyrite \\
\hline $3 \mathrm{H}-4,91-93$ & 17.61 & 0.3 & 227 & 9 & 87 & Mud, fault & Pyrite, forams \\
\hline $3 \mathrm{H}-4,117-119$ & 17.87 & 0.7 & 610 & 9 & 44 & Mud & Forams, pyrite \\
\hline $3 \mathrm{H}-5,74-76$ & 18.94 & 0.2 & 232 & 27 & 28 & Mud & Forams, pyrite, test fragments very abundant \\
\hline $3 \mathrm{H}-5,78-80$ & 18.98 & 0.3 & 414 & 13 & 29 & Mud & Pyrite, forams \\
\hline $3 \mathrm{H}-5,96-98$ & 19.16 & 0.5 & 381 & 12 & 12 & Mud & Forams, pyrite, silt lumps \\
\hline $3 \mathrm{H}-5,108-110$ & 19.28 & 2.0 & & & 17 & Mud & Mineral grains, forams, pyrite \\
\hline $3 \mathrm{H}-5,130-132$ & 19.50 & 0.6 & 827 & 6 & 29 & Mud & Forams, pyrite \\
\hline $3 \mathrm{H}-6,92-94$ & 20.62 & 4.3 & 11811 & 7 & 97 & Mud & Forams, overgrowths, cement, horns \\
\hline $3 \mathrm{H}-7,39-41$ & 21.59 & 0.6 & 0 & & & Dark mud & Mineral grains, pyrite, forams, overgrowths, cemented mineral grains \\
\hline $4 \mathrm{H}-1,82-84$ & 22.52 & 0.8 & 389 & 30 & 96 & Top fus & Forams, pyrite, strong overgrowths \\
\hline $4 \mathrm{H}-2,81-83$ & 24.01 & 1.2 & 760 & 6 & 97 & Top fus & Forams, pyrite, strong overgrowths \\
\hline $4 \mathrm{H}-3,122-124$ & 25.92 & 1.4 & 1541 & 2 & 99 & Top fus & Forams, pyrite, strong overgrowths \\
\hline $4 \mathrm{H}-4,88-90$ & 27.08 & 0.9 & 29 & 20 & 91 & Top fus & Cemented mineral grains, rare forams, overgrowths \\
\hline $4 \mathrm{H}-5,96-98$ & 28.66 & 3.4 & 3947 & 3 & 97 & Top fus & Forams, overgrowths \\
\hline $4 \mathrm{H}-6,108-110$ & 30.23 & 13.0 & 1526 & 9 & 99 & Silty blebs & Mineral grains, rare forams, overgrowths, cement \\
\hline $4 \mathrm{H}-7,62-64$ & 31.32 & 0.5 & 446 & 3 & 99 & Mud & Forams, mineral grains, overgrowths, cemented grains on forams \\
\hline $5 \mathrm{H}-1,19-21$ & 31.39 & 3.4 & 3999 & 2 & 100 & Top fus & Forams, mineral grains, overgrowths, cemented grains on forams \\
\hline $5 \mathrm{H}-2,6-8$ & 31.64 & 1.3 & 265 & 62 & 100 & Top fus & Mineral grains, forams, overgrowths \\
\hline $5 \mathrm{H}-3,135-137$ & 34.43 & 9.9 & 339 & 44 & 100 & Top fus & Mineral grains, forams, overgrowths, cemented silt lumps \\
\hline $5 \mathrm{H}-4,88-90$ & 35.46 & 3.1 & 3952 & 2 & 100 & Top fus & Forams, pyrite, overgrowths \\
\hline $5 \mathrm{H}-5,133-135$ & 37.41 & 2.0 & 431 & 39 & 99 & Top fus & Mineral grains, rare forams, some with overgrowths \\
\hline $5 \mathrm{H}-6,90-92$ & 38.48 & 0.7 & & & & Top fus & Mineral grains, forams, pyrite, overgrowths, mixed preservation \\
\hline $5 \mathrm{H}-7,88-90$ & 39.96 & 3.5 & 475 & 58 & 100 & Silty & Mineral grains, pyrite, forams, overgrowths \\
\hline $6 \mathrm{H}-1,68-70$ & 41.38 & 2.5 & 448 & 54 & 99 & Silty & Mineral grains, forams, pyrite, overgrowths \\
\hline $6 \mathrm{H}-2,123-125$ & 43.43 & 0.2 & 17 & 75 & 100 & Top fus & Cemented silt lumps, forams, pyrite, overgrowths \\
\hline $6 \mathrm{H}-3,127-129$ & 44.97 & 2.4 & 3872 & 6 & 100 & Top fus & Forams, pyrite, overgrowths \\
\hline $6 \mathrm{H}-4,138-140$ & 46.58 & 4.7 & 0 & & & Top fus & Mineral grains \\
\hline $6 \mathrm{H}-5,73-75$ & 47.43 & 3.5 & 0 & & & Silty & Mineral grains \\
\hline $6 \mathrm{H}-6,46-48$ & 48.66 & 0.2 & 243 & 53 & 99 & Top fus & Mineral grains, forams, overgrowths \\
\hline $6 \mathrm{H}-6,112-114$ & 49.32 & 1.4 & 108 & 9 & 100 & Top fus & Mineral grains, forams, overgrowths \\
\hline $7 \mathrm{H}-1,48-50$ & 50.68 & 4.7 & 273 & 38 & 100 & Silty & Mineral grains, forams, overgrowths \\
\hline $7 \mathrm{H}-2,12-14$ & 51.82 & 4.0 & 1049 & 13 & 100 & Top fus & Forams, mineral grains, pyrite, overgrowths \\
\hline $7 \mathrm{H}-2,101-103$ & 52.71 & 5.5 & 0 & & & Silty & Mineral grains \\
\hline $7 \mathrm{H}-4,64-66$ & 55.34 & 27.0 & 0 & & & Silty & Mineral grains \\
\hline $7 \mathrm{H}-4,94-96$ & 55.64 & 20.3 & 0 & & & Silty & Mineral grains \\
\hline $7 \mathrm{H}-5,46-48$ & 56.66 & 16.9 & 0 & & & Silty & Mineral grains \\
\hline $7 \mathrm{H}-6,39-41$ & 58.09 & 4.8 & 0 & & & Silty & Mineral grains \\
\hline $7 \mathrm{H}-7,23-25$ & 59.43 & 3.4 & 0 & & & Silty & Mineral grains \\
\hline $8 \mathrm{H}-1,87-90$ & 60.57 & 0.0 & 0 & & & Top fus & Pyrite, sulfate(?) crystals, agglut forams \\
\hline $8 \mathrm{H}-2,119-121$ & 62.39 & 9.2 & 0 & & & Silty & Mineral grains, pyrite \\
\hline $8 \mathrm{H}-3,120-123$ & 63.90 & 0.1 & 0 & & & Mud & Mineral grains, agglut forams, sulfate(?) crystals \\
\hline $8 \mathrm{H}-4,112-115$ & 65.32 & 0.4 & 0 & & & Mud & Mineral grains \\
\hline $8 \mathrm{H}-5,98-101$ & 66.68 & 2.7 & 0 & & & Mud & Mineral grains, rare forams with overgrowths \\
\hline $8 \mathrm{H}-6,94-98$ & 68.14 & 1.8 & 0 & & & Mud & Mineral grains, pyrite, forams, cemented mineral lumps \\
\hline $9 \mathrm{H}-1,127-129$ & 70.47 & 0.1 & 0 & & & Mud & Pyrite, agglut forams, sulfate(?) crystals \\
\hline $9 \mathrm{H}-2,122-124$ & 71.92 & 0.5 & 0 & & & Top fus & Mineral grains, pyrite, agglut forams \\
\hline $9 \mathrm{H}-3,90-92$ & 73.10 & 0.4 & 0 & & & Top fus & Agglut forams, pyrite, cemented mineral grains \\
\hline $9 \mathrm{H}-4,97-99$ & 74.67 & 1.5 & 0 & & & Top fus & Agglut forams, mineral grains, pyrite \\
\hline $9 \mathrm{H}-5,127-129$ & 76.47 & 0.6 & 0 & & & Top fus & Cemented silt lumps, pyrite, rare recrystallized benthics, agglut forams \\
\hline $9 \mathrm{H}-6,46-48$ & 77.16 & 0.1 & 6 & 0 & 100 & Mud & Pyrite, mineral grains, forams (white) \\
\hline $10 X-1,20-23$ & 78.90 & 0.7 & 0 & & & Top fus & Cemented silt lumps, pyrite, sulfate(?) crystals \\
\hline $10 X-2,85-88$ & 81.05 & 0.7 & 0 & & & Top fus & Mineral grains, cemented silt lumps \\
\hline $11 X-1,12-14$ & 86.32 & 1.5 & 0 & & & Top fus & Silt lumps, magnetite, pyrite, lumps $>500 \mu \mathrm{m}$ \\
\hline $11 X-2,8-10$ & 87.78 & 17.5 & 0 & & & Top fus & Silt lumps, some lumps $>500 \mu \mathrm{m}$ \\
\hline $11 \times-2,10-12$ & 87.80 & 19.9 & 0 & & & Top fus & Silt lumps, pyrite, lumps $>500 \mu \mathrm{m}$ \\
\hline $12 X-1,33-35$ & 96.03 & 1.8 & & & & Top fus & Mineral grain lumps, pyrite, brown recrystallized forams \\
\hline $12 X-2,32-34$ & 97.52 & 9.9 & & & & Drill sand & Pyrite, mineral grains, brown forams \\
\hline $13 X-1,65-67$ & 105.95 & 0.7 & 0 & & & Mud & Silt lumps, pyrite, mineral grains \\
\hline $13 X-2,57-60$ & 107.37 & 0.3 & 0 & & & Top fus & Silt lumps \\
\hline $13 X-3,4-6$ & 108.34 & 25.9 & 0 & & & Mud & Cemented silt lumps, pyrite, mineral grains, lumps $>500 \mu \mathrm{m}$ \\
\hline $13 X-4,87-89$ & 110.67 & 15.6 & 0 & & & Mud & Mineral grains, pyrite, lumps $>500 \mu \mathrm{m}$ \\
\hline $13 X-5,18-20$ & 111.48 & 23.6 & 0 & & & Drill mud & Cemented silt lumps, pyrite, mineral grains, lumps $>500 \mu \mathrm{m}$ \\
\hline
\end{tabular}

Notes: $\mathrm{mbsf}=$ meters below seafloor; Sand = percent greater than 63 micrometer fraction by weight; Fno $=$ foraminiferal number $($ test $/ \mathrm{g}$ ); $\mathrm{B} / \mathrm{P}=\mathrm{relative}$ frequency of benthic foraminifers to total number of foraminifers: Coil = relative frequency of sinistral Nq. pachyderma to total number of $N q$. pachyderma; Lith = lithology; Mud = unconsolidated silty clay or clayey silt; Top fus = muddy top of a fining upward sequence; Silty = sample contains silty blebs, wisps, or layers; Claystone $=$ consolidated silty clay or clayey silt; Constituents of the sand size fraction are ranked in order of greatest abundance; forams $=$ planktonic and/or benthic foraminifers. 
Table 2. Constituents of the sand-size fraction, Holes $857 \mathrm{~A}$ and $857 \mathrm{C}$.

\begin{tabular}{|c|c|c|c|c|c|c|c|}
\hline $\begin{array}{l}\text { Core, section, } \\
\text { interval }(\mathrm{cm})\end{array}$ & $\begin{array}{l}\text { Depth } \\
\text { (mbsf) }\end{array}$ & Sand & Fno & $\mathrm{B} / \mathrm{P}$ & Coil & Lith & Constituents of the sand-size fraction \\
\hline \multicolumn{8}{|l|}{ 139-857A- } \\
\hline $1 \mathrm{H}-1,0-1$ & 1.90 & & & 8 & 85 & Mud & Forams \\
\hline $1 \mathrm{H}-1,79-81$ & 2.69 & 1.8 & 1287 & 2 & 97 & Silty & Forams, mineral grains, pyrite \\
\hline $1 \mathrm{H}-2,125-129$ & 4.65 & 1.0 & 1606 & 2 & 99 & Silty & Forams, mineral grains, pyrite \\
\hline $1 \mathrm{H}-3,10-13$ & 5.00 & 1.8 & 5864 & 1 & 100 & Mud & Forams \\
\hline $1 \mathrm{H}-3,23-27$ & 5.13 & 1.7 & & & & Silty & Forams, pyrite \\
\hline $1 \mathrm{H}-4,72-76$ & 7.12 & 0.4 & 1 & 13 & 100 & Silty & Mineral grains, pyrite \\
\hline $1 \mathrm{H}-5,89-91$ & 8.79 & 1.3 & 5331 & 1 & 100 & Mud & Forams, pyrite \\
\hline $1 \mathrm{H}-6,36-38$ & 9.76 & 1.0 & 2805 & 4 & 99 & Silty & Forams, pyrite \\
\hline $2 \mathrm{H}-1,45-48$ & 11.85 & & & 7 & 100 & Mud & Forams, pyrite \\
\hline $2 \mathrm{H}-1,97-99$ & 12.37 & 1.2 & 2784 & 4 & 99 & Mud & Forams, pyrite \\
\hline $2 \mathrm{H}-1,105-107$ & 12.45 & & & 9 & 99 & Silty & Forams, pyrite \\
\hline $2 \mathrm{H}-2,20-22$ & 13.10 & & & 2 & 100 & Top fus & Forams, pyrite \\
\hline $2 \mathrm{H}-2,96-98$ & 13.86 & 1.4 & 2999 & 4 & 100 & Top fus & Forams, pyrite \\
\hline $2 \mathrm{H}-2,129-131$ & 14.19 & & & 9 & 100 & Mud & Forams, pyrite \\
\hline $2 \mathrm{H}-3,98-100$ & 15.38 & 0.1 & 356 & 5 & 98 & Mud & Forams, pyrite \\
\hline $2 \mathrm{H}-3,129-131$ & 15.69 & & & 21 & 100 & Mud & Forams, pyrite \\
\hline $2 \mathrm{H}-4,12-14$ & 16.02 & & & 16 & 99 & Mud & Pyrite tubes, forams, mineral grains \\
\hline $2 \mathrm{H}-4,98-100$ & 16.88 & 0.3 & 526 & 14 & 99 & Top fus & Forams, pyrite \\
\hline $2 \mathrm{H}-4,127-129$ & 17.17 & & & 22 & 99 & Mud & Forams, pyrite \\
\hline $2 \mathrm{H}-5,7-9$ & 17.47 & 0.6 & 444 & 10 & 99 & Mud & Pyrite tubes, forams \\
\hline $2 \mathrm{H}-5,22-24$ & 17.62 & & & 7 & 100 & Mud & Forams, pyrite \\
\hline $2 \mathrm{H}-6,9-11$ & 18.99 & & & 11 & 98 & Top fus & Forams, pyrite, some yellow tests \\
\hline $2 \mathrm{H}-6,93-95$ & 19.83 & 0.3 & & & & Mud & Silt lumps, forams, pyrite \\
\hline $2 \mathrm{H}-7,26-28$ & 20.66 & 0.4 & 715 & 11 & 98 & Top fus & Pyrite, forams \\
\hline $4 \mathrm{H}-\mathrm{I}, 124-126$ & 23.14 & 1.5 & & & & Silty & Mineral grains, pyrite, forams \\
\hline $4 \mathrm{H}-2,105-107$ & 24.45 & & & & 100 & Mud & Pyrite, forams, sponge \\
\hline $4 \mathrm{H}-2,118-122$ & 24.58 & 1.8 & 0 & & & Silty & Mineral grains, pyrite \\
\hline $4 \mathrm{H}-3,64-66$ & 25.54 & 0.2 & 27 & 38 & 98 & Top fus & Pyrite, forams, mineral grains \\
\hline $4 \mathrm{H}-3,100-103$ & 25.90 & 3.4 & & & & Silt layer & Mineral grains, pyrite, forams, rad \\
\hline $4 \mathrm{H}-3,115-117$ & 26.05 & & & & 97 & Mud & Mineral grains, silt lumps, forams \\
\hline $4 \mathrm{H}-3,125-127$ & 26.15 & 0.6 & 281 & 19 & 99 & Mud & Forams, radiolarians, pyrite \\
\hline $4 \mathrm{H}-4,12-14$ & 26.52 & 0.7 & 70 & 55 & 90 & Mud & Pyrite, forams, diatoms, radiolarians \\
\hline $4 \mathrm{H}-4,30-32$ & 26.70 & 1.2 & 23 & 47 & 96 & Mud & Pyrite, mica, forams, radiolarians \\
\hline $4 \mathrm{H}-4,38-40$ & 26.78 & 0.6 & & & 90 & Mud & Forams, pyrite, radiolarians, diatoms \\
\hline $4 \mathrm{H}-4,49-51$ & 26.89 & & & 26 & 78 & Top fus & Forams, silt lumps, pyrite \\
\hline $4 \mathrm{H}-4,59-61$ & 26.99 & 0.1 & & & 100 & Mud & Radiolarians, forams, pyrite \\
\hline $4 \mathrm{H}-4,70-74$ & 27.10 & 0.1 & 10 & 73 & 96 & Top fus & Pyrite, forams \\
\hline $4 \mathrm{H}-5,40-44$ & 28.30 & 0.2 & 256 & 11 & 99 & Mud & Forams, pyrite \\
\hline $4 \mathrm{H}-5,127-129$ & 29.17 & & & & 100 & Silty & Forams, pyrite, mineral grains \\
\hline $4 \mathrm{H}-7,43-47$ & 31.33 & 0.4 & 638 & 11 & 95 & Mud & Forams, pyrite \\
\hline $5 \mathrm{H}-2,13-17$ & 33.03 & 0.1 & 40 & 18 & 98 & Mud & Pyrite, mineral grains, forams \\
\hline $5 \mathrm{H}-2,38-42$ & 33.28 & 2.4 & 0 & & & Silt layer & Mineral grains \\
\hline $5 \mathrm{H}-3,48-52$ & 34.88 & 0.6 & 0 & & & Silty & Mineral grains, pyrite \\
\hline $5 \mathrm{H}-4,9-13$ & 35.99 & & & 39 & 90 & Silty & Forams, rads, pyrite \\
\hline $5 \mathrm{H}-4,43-45$ & 36.33 & 1.5 & & & 67 & Mud & Mineral grains, pyrite, radiolarians, forams \\
\hline $5 \mathrm{H}-4,57-6 \mathrm{I}$ & 36.47 & 3.1 & 260 & 25 & 72 & Silty & Mineral grains, forams, radiolarians \\
\hline $5 \mathrm{H}-4,70-72$ & 36.60 & 0.4 & 56 & 16 & 71 & Mud & Radiolarians, diatoms, pyrite, forams \\
\hline $5 \mathrm{H}-4,130-132$ & 37.20 & 0.9 & 212 & 25 & 78 & Mud & Radiolarians, forams, diatoms, pyrite \\
\hline $5 \mathrm{H}-5,105-107$ & 38.45 & 0.5 & 269 & 18 & 10 & Mud & Radiolarians, pyrite, forams \\
\hline $5 \mathrm{H}-5,118-120$ & 38.58 & 0.5 & 0 & & & Mud & Mica, pyrite, diatoms, radiolarians, forams \\
\hline $5 \mathrm{H}-5,126-130$ & 38.66 & 2.2 & & & 20 & Silty & Mineral grains, radiolarians, forams \\
\hline $5 \mathrm{H}-5,140-142$ & 38.80 & 0.7 & 890 & 8 & 8 & Mud & Radiolarians, pyrite, forams, mica \\
\hline $5 \mathrm{H}-6,126-130$ & 40.16 & 2.6 & 0 & & 81 & Silty & Mineral grains \\
\hline $5 \mathrm{H}-7,18-22$ & 40.58 & 1.8 & & & 100 & Silty & Mineral grains, pyrite, forams \\
\hline $6 \mathrm{H}-1,59-63$ & 41.49 & 1.0 & 3142 & 1 & 99 & Mud & Forams, pyrite \\
\hline $6 \mathrm{H}-2,76-80$ & 43.16 & 1.2 & 807 & 1 & 97 & Mud & Forams, pyrite \\
\hline $6 \mathrm{H}-6,84-86$ & 49.24 & 0.1 & & & & Mud & Forams \\
\hline 7H-3, 37-39 & 52.59 & 0.4 & 897 & 6 & 99 & Mud & Forams, pyrite, mineral grains \\
\hline $7 \mathrm{H}-4,85-89$ & 54.47 & 2.2 & 5688 & 1 & 97 & Mud & Forams \\
\hline $7 \mathrm{H}-5,75-79$ & 55.52 & 0.4 & 1247 & 3 & 96 & Top fus & Forams \\
\hline $7 \mathrm{H}-6,121-125$ & 56.59 & 0.3 & 980 & 4 & 100 & Mud & Forams, pyrite \\
\hline $7 \mathrm{H}-7,28-32$ & 57.35 & 0.0 & 7 & 6 & 98 & Mud & Pyrite tubes, forams \\
\hline $8 \mathrm{H}-1,119-123$ & 61.09 & 4.1 & 1602 & 2 & 99 & Mud & Mineral grains, forams \\
\hline $8 \mathrm{H}-2,21-25$ & 61.61 & 0.5 & 1061 & 3 & 100 & Mud & Forams, pyrite \\
\hline $8 \mathrm{H}-3,54-58$ & 63.44 & 1.4 & 1468 & 3 & 99 & Silty & Mineral grains, forams \\
\hline $8 \mathrm{H}-4,43-47$ & 64.83 & 0.6 & 2027 & 4 & 99 & Mud & Forams, pyrite \\
\hline $8 \mathrm{H}-5,40-44$ & 66.30 & 0.3 & 277 & 8 & 100 & Mud & Forams, pyrite \\
\hline $8 \mathrm{H}-5,114-118$ & 67.04 & & & 2 & 100 & Mud & Forams \\
\hline $8 \mathrm{H}-6,52-56$ & 67.92 & 0.2 & 766 & 2 & 99 & Mud & Forams, pyrite \\
\hline $8 \mathrm{H}-7,22-26$ & 69.12 & 0.2 & 8 & 29 & 100 & Mud & Pyrite tubes, forams \\
\hline $9 \mathrm{H}-1,89-91$ & 70.29 & 2.0 & & & & Mud & Pyrite, rare forams \\
\hline $9 \mathrm{H}-2,90-92$ & 71.80 & 1.2 & & & & Mud & Pyrite, forams, mineral grains \\
\hline $9 \mathrm{H}-3,74-80$ & 73.14 & 0.2 & 717 & 2 & 100 & Mud & Forams, pyrite \\
\hline $9 \mathrm{H}-4,60-63$ & 74.50 & 1.4 & 348 & 5 & 100 & Mud & Pyrite, forams, mineral grains \\
\hline $9 \mathrm{H}-5,79-84$ & 76.19 & & & 1 & 98 & Mud & Forams, pyrite \\
\hline $10 \mathrm{H}-1,124-27$ & 80.14 & 0.1 & 350 & 3 & 99 & Mud & Forams, pyrite \\
\hline $10 \mathrm{H}-2,12-14$ & 80.52 & & & 5 & 99 & Mud & Forams, silt lumps \\
\hline $10 \mathrm{H}-4,99-01$ & 84.39 & 0.1 & 94 & 2 & 100 & Mud & Forams, pyrite \\
\hline $10 \mathrm{H}-5,32-34$ & 85.22 & & 0 & & & Mud & Silt lumps, pyrite \\
\hline $10 \mathrm{H}-6,12-14$ & 86.52 & & 0 & & & Silty & Mineral grains \\
\hline $13 \mathrm{X}-1,9-11$ & 101.59 & 0.4 & 0 & & & Claystone & Sulfate(?) crystals, pyrite, mineral grains \\
\hline $13 X-2,63-67$ & 103.63 & 0.8 & & & & Claystone & Forams, cemented silt lumps, pyrite, mineral grains \\
\hline $13 X-2,68-72$ & 103.68 & & 0 & & & Claystone & Cemented mineral grains \\
\hline $13 X-3,90-92$ & 105.40 & 3.1 & & & & Top fus & Mineral grains, forams \\
\hline $13 X-4,95-97$ & 106.95 & 0.8 & 0 & & & Claystone & Cemented silt lumps \\
\hline
\end{tabular}


Table 2 (continued).

\begin{tabular}{|c|c|c|c|c|c|c|c|}
\hline $\begin{array}{l}\text { Core, section, } \\
\text { interval }(\mathrm{cm})\end{array}$ & $\begin{array}{l}\text { Depth } \\
\text { (mbsf) }\end{array}$ & Sand & Fno & $\mathrm{B} / \mathrm{P}$ & Coil & Lith & Constituents of the sand-size fraction \\
\hline $13 X-5,6-8$ & 107.56 & 1.8 & & & & Claystone & Silt lumps, forams \\
\hline $13 \times-5,88-90$ & 108.38 & 4.9 & 0 & & & Silty & Mineral grains \\
\hline \multicolumn{8}{|l|}{$139-857 \mathrm{C}$ - } \\
\hline $9 \mathrm{R}-1,96-98$ & 115.46 & 0.3 & 0 & & & Claystone & Mineral grains, sulfate(?) crystals, orange pollen \\
\hline $10 \mathrm{R}-1,33-35$ & 124.28 & & & & & Claystone & Pyrite tubes, orange forams \\
\hline $11 \mathrm{R}-1,52-54$ & 134.32 & & & & & Claystone & Mineral grains, cemented silt lumps, pyrite, white forams \\
\hline $12 \mathrm{R}-1,91-94$ & 144.41 & 0.0 & & & & Claystone & Cemented silt lumps, pyrite, sulfate(?) crystals, white forams \\
\hline $12 \mathrm{R}-2,31-33$ & 145.31 & & & & & Claystone & Cemented sand lumps, sulfate(?) crystals, pyrite, recrystallized forams \\
\hline $13 \mathrm{R}-1,48-50$ & 153.58 & 0.0 & & & & Claystone & Cemented silt lumps, pyrite, recrystallized forams, a few are brownish \\
\hline $14 \mathrm{R}-1,35-39$ & 163.15 & 0.5 & 0 & & & Claystone & Cemented silt lumps \\
\hline $14 \mathrm{R}-2,68-70$ & 164.98 & 0.6 & & & & Claystone & Mineral grains, cemented silt lumps some $>500 \mu \mathrm{m}$, light brown recrystal. forams \\
\hline $15 \mathrm{R}-1,32-34$ & 172.82 & 0.1 & 0 & & & Claystone & Mineral grains, sulfate(?) crystals, pyrite \\
\hline $15 R-2,40-42$ & 174.40 & 0.1 & 0 & & & Claystone & Sulfate(?) crystals \\
\hline $15 \mathrm{R}-3,12-14$ & 175.62 & 0.2 & & & & Claystone & Calcite crystals, light brown forams with overgrowths, some lumps $>500 \mu \mathrm{m}$ \\
\hline $15 \mathrm{R}-4,10-14$ & 177.10 & 45.3 & 0 & & & Claystone & Cemented silt lumps, pyrite, some lumps $>500 \mu \mathrm{m}$ \\
\hline $15 \mathrm{R}-5,17-20$ & 178.67 & 19.4 & 0 & & & Claystone & Cemented silt lumps, some lumps $>500 \mu \mathrm{m}$ \\
\hline $16 \mathrm{R}-1,7-9$ & 182.27 & 0.5 & 0 & & & Claystone & Cemented silt lumps, pyrite \\
\hline $17 \mathrm{R}-1,49-51$ & 192.39 & 0.2 & 0 & & & Claystone & Cemented silt grains, pyrite, mineral grains, some lumps $>500 \mu \mathrm{m}$ \\
\hline $18 \mathrm{R}-1,49-51$ & 202.09 & 28.1 & 0 & & & Claystone & Cemented silt lumps, pyrite, some lumps $>500 \mu \mathrm{m}$ \\
\hline $19 \mathrm{R}-1,45-47$ & 211.75 & 36.0 & 0 & & & Claystone & Cemented silt lumps, some lumps $>500 \mu \mathrm{m}$ \\
\hline
\end{tabular}

Notes: $\mathrm{mbsf}=$ meters below seafloor, Sand $=$ percent greater than 63 micrometer fraction by weight; Fno $=$ foraminiferal number $($ test $/ \mathrm{g}$ ); $\mathrm{B} / \mathrm{P}=$ relative frequency of benthic foraminifers to total number of foraminifers; Coil = relative frequency of sinistral Nq. pachyderma to total number of $N q$. pachyderma; Lith = lithology; Mud = unconsolidated silty clay or clayey silt; Top fus = muddy top of a fining upward sequence; Silty = sample contains silty blebs, wisps, or layers; Claystone = consolidated silty clay or clayey silt; Constituents of the sand size fraction are ranked in order of greatest abundance; forams = planktonic and/or benthic foraminifers; rads $=$ radiolarians.

A
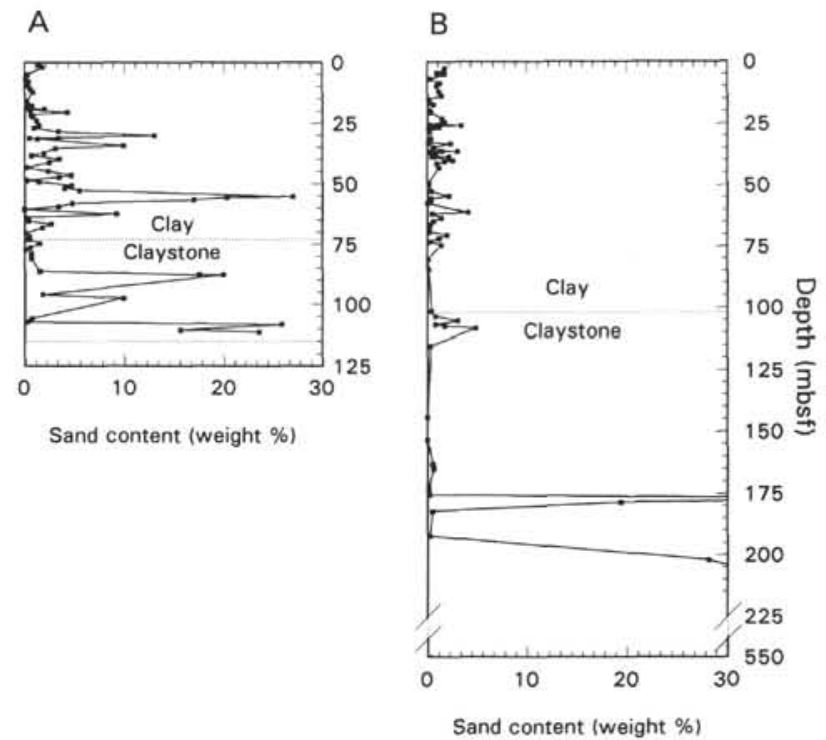

Figure 1. Sand contents of samples in (A) Hole 856A and (B) Holes 857 A and $857 \mathrm{C}$ measured by the percent by weight of particles greater than $63 \mu \mathrm{m}$ in diameter. The depths of the first semilithified samples are marked by the upper dotted lines. The top of a basaltic sill at the base of Hole 856A is marked by the second dotted line in A. Hole 857 A terminated in sediment interlayed with sills.

Table 3. Statistics on constituents of the sand-size fraction.

\begin{tabular}{|c|c|c|c|c|c|c|}
\hline \multirow{2}{*}{$\begin{array}{c}\text { Statistical } \\
\text { terms }\end{array}$} & \multicolumn{3}{|c|}{ Hole $856 \mathrm{~A}$} & \multicolumn{3}{|c|}{ Holes $857 \mathrm{~A}$ and $857 \mathrm{C}$} \\
\hline & Sand & Fno & $\mathrm{B} / \mathrm{P}$ & Sand & Fno & $\mathrm{B} / \mathrm{P}$ \\
\hline Median & 1.4 & 446 & 9 & 0.6 & 638 & 7 \\
\hline Mean & 4.2 & 1505 & 21 & 2.6 & 1145 & 12 \\
\hline Number of samples & 70 & 37 & 38 & 77 & 43 & 58 \\
\hline
\end{tabular}

Notes: Sand $=$ percent by weight $>63 \mu \mathrm{m} ;$ Fno $=$ planktonic foraminiferal number (tests/gm of sediment); BP = frequency of benthic foraminifers (benthic tests/total foraminiferal tests). mixture of grains from both depositional regimes. Some samples (22) were semi-indurated claystone in which sediment texture and structure were difficult to determine based on the core photos. Presence of sandsize aluminosilicate mineral grains suggests that 10 of the claystones contain some turbiditic sediment. Some samples (77) were taken from muddy units with no recognizable structure. These samples have a higher probability of being hemipelagic than do samples from the other types of units.

The constituents in the sand-size fraction of the muds and tops of fining upward sequences (Tables 1 and 2) support the contention that many of these samples could be hemipelagic rather than turbiditic in depositional origin. Most samples from muds (52 of 77 samples) are composed of pelagic grains such as authigenic pyrite, radiolarians, and foraminifers, whereas 25 samples contain various amounts of aluminosilicate mineral grains. Almost one third of the samples from the tops of fining upward sequences (15 of 43) consist of pelagic constituents, usually foraminifers with various amounts of authigenic pyrite, and the remainder contain either sand-size mineral grains or cemented silt lumps. The lithologic results make clear that the micropaleontologic data at Sites 856 and 857 must be interpreted with caution. Only about $40 \%$ of the samples in the data set are likely to be hemipelagic (67 of 176), and the remainder are either turbiditic or the style of deposition is obscured by postdepositional effects. Turbiditic samples will be flagged on graphs used for biostratigraphy and paleoenvironmental analysis.

Comparison of the constituents of the sand-size fractions of Hole $856 \mathrm{~A}$ and Hole $857 \mathrm{~A}$ reveal distinctive trends (Table 3 ). The sand content (percent by weight) at Hole $856 \mathrm{~A}$ is significantly greater than the sand content at Holes $857 \mathrm{~A}$ and $857 \mathrm{C}$. More significance is given to the comparison of medians because the distributions are not normal. At Site 857 (Table 2; Fig. 1), only four samples have sand contents above $5 \%$, and these are semilithified sediments from the base of Hole 857A and from underlying depths at Hole $857 \mathrm{C}$. In contrast, Hole $856 \mathrm{~A}$ has 13 samples coarser than 5\% (Table 1; Fig. 1): five of these are slightly indurated sediments from the deepest three cores, six are dominated by aluminosilicate mineral sands, and one is filled with pyrite. Most samples that contain $1 \%$ to $5 \%$ sand at either site contain abundant mineral grains, pyrite, or sometimes planktonic foraminifers, but some samples below $18.5 \mathrm{mbsf}$ at Hole $856 \mathrm{~A}$ are coarse because grains have been cemented together into sand-size lumps. 
A

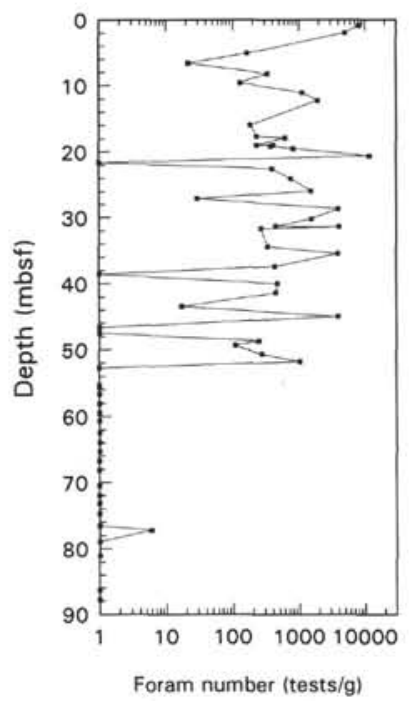

B

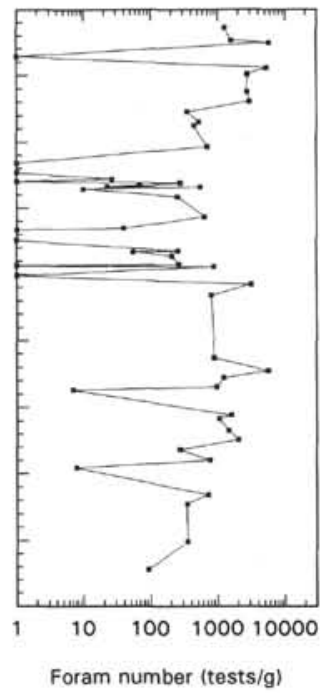

Figure 2. Foraminiferal numbers of samples in (A) Hole 856A and (B) Hole $857 \mathrm{~A}$ measured by the number of planktonic foraminiferal tests per gram of dry bulk sediment.

\section{Fossil Abundance}

Planktonic foraminifers are abundant at Hole $856 \mathrm{~A}$ in most sections above $52 \mathrm{mbsf}$, but occur rarely and sporadically below this depth. They are abundant at Holes 857A and $857 \mathrm{C}$ above $85 \mathrm{mbsf}$, but are rare and sporadic from $85 \mathrm{mbsf}$ to $221 \mathrm{mbsf}$, absent to $332 \mathrm{mbsf}$, sporadic to $390 \mathrm{mbsf}$, and barren to the bottom of the hole at 558 mbsf. Planktonic foraminiferal number (tests/g) was determined in samples above 52 and $85 \mathrm{mbsf}$, respectively, in Holes $856 \mathrm{~A}$ and $857 \mathrm{~A}$ (Tables 1, 2, and 3; Fig. 2). The median of Hole 857A is larger than that of $856 \mathrm{~A}$, but Hole $856 \mathrm{~A}$ has the two highest planktonic foraminiferal numbers. At both holes, samples with less than $1 \%$ sand content also have foraminiferal numbers below 2000 test/g.

The frequency of benthic foraminifers (benthic foraminiferal tests/ [planktonic + benthic foraminiferal tests]) was determined in samples above 52 and 85 mbsf, respectively, in Holes 856A and 857A (Tables 1, 2, and 3; Fig. 3). Benthic foraminiferal frequencies have similar medians (9 and 7) at the two holes (Table 3), but the distributions are different. Hole $856 \mathrm{~A}$ has more samples with high or low frequencies and Hole $857 \mathrm{~A}$ has more samples with intermediate frequencies. All samples with large foraminiferal numbers $(>2000$ tests/g) have relatively low benthic test frequencies $(<6 \%)$, and all samples with a benthic test frequency $>15 \%$ have very low foraminiferal numbers $(<500$ test/g).

\section{Fossil Preservation}

The preservation state of foraminifers at Holes $856 \mathrm{~A}, 857 \mathrm{~A}$, and $857 \mathrm{C}$ reflects effects of thermal and hydrothermal alteration. Foraminifers in the fossil-rich upper sequence from 19 to $52 \mathrm{mbsf}$ at Hole $856 \mathrm{~A}$ bear calcite overgrowths. The overgrowths frost many specimens and have grown to distinct protuberances (wart- and hornshaped) on specimens from 22 to $26 \mathrm{mbsf}$. Foraminifers from deep in the sequences appear recrystallized and are a distinctive light brown color. Such specimens occur below $96 \mathrm{mbsf}$ at Hole 856A and below $153 \mathrm{mbsf}$ at Hole $857 \mathrm{C}$. The preservation state is best exemplified in Sample 857C-40R-CC, which bears abundant planktonic foraminifers. All tests are a distinct brown color rather than white, and many tests are deformed in shape by stretching or flattening. The brown color may be produced by maturation of glycosaminoglycan mem-

A

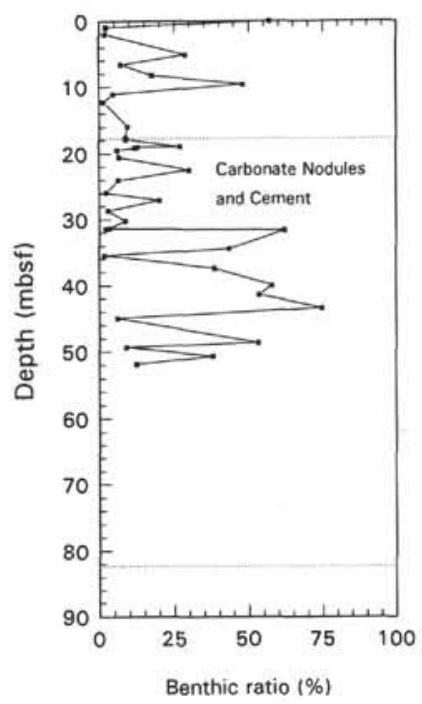

B

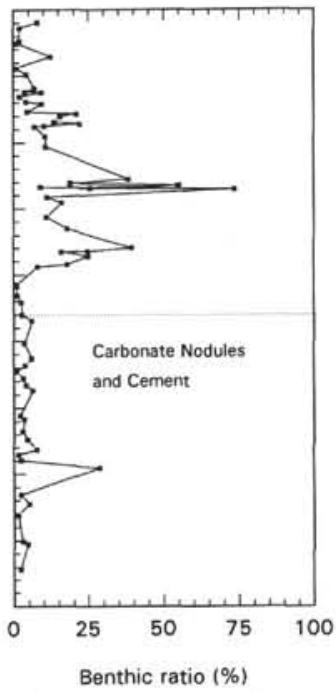

Figure 3. Benthic ratios of samples in (A) Holes 856A and 857A (B) measured by the frequency of benthic foraminifers relative to benthic plus planktonic foraminifers. Intervals where carbonate nodules and cement occur are marked between dotted lines in $\mathbf{A}$ and below the dotted line in $\mathbf{B}$.

branes that lie between layers of calcite crystals in planktonic foraminiferal tests (Langer, 1992).

\section{Biostratigraphy}

\section{Top of Holocene and Holocene-Pleistocene Boundary}

The core tops were sampled from the 11 holes considered here. Samples from the surface (zone of bioturbation) were recognized based on the presence of a characteristic assemblage of agglutinated foraminifers (Table 4). The assemblage includes Ammodiscus, Hormosina, Saccammina, several types of tube fragments, Ammodiscus, Haplophragmoides, Cribrostomoides, and sporadic occurrences of other genera. None of these taxa was found below the topmost sample at any hole in this study. Delicate agglutinated taxa may be restricted to the surface because cements dissolve after burial (Sidner and McKee, 1976). Nine of the eleven core tops bear the agglutinated assemblage and are, therefore, from the surface layer (Holes $885 \mathrm{~A}$, $855 \mathrm{C}, 856 \mathrm{~A}, 856 \mathrm{~B}, 857 \mathrm{~B}, 857 \mathrm{C}, 858 \mathrm{~A}, 858 \mathrm{C}$, and $858 \mathrm{D})$. Two samples lack the agglutinated foraminifers. The core top from Hole 857A contains abundant benthic and planktonic foraminifers, but no agglutinated taxa. The core top cannot be from the surface. The core top from Hole $858 \mathrm{~B}$ is barren of all microfossils and contains only hydrothermal anhydrite. Its relation to the surface is uncertain.

The age of core top samples was examined using the coiling ratio of Nq. pachyderma and verified using abundance of siliceous microfossils (Table 5). Dextral forms dominate Holocene and latest Pleistocene age sediment (after 14,000 yr) and sinistral forms dominate late Pleistocene sediments of the North Pacific Ocean (Bandy, 1960; Brunner and Ledbetter, 1987; Gardner et al., 1988). The age based on coiling ratio was further corroborated using the abundance of radiolarians and diatoms which dominate biogenic sediment of the Holocene northeast Pacific Ocean after 7000 yr ago (Duncan et al., 1970; Karlin et al., 1992). All samples that bear the surface marker assemblage of agglutinated foraminifers are also Holocene in age (Table 4) based on the coiling ratio of $N q$. pachyderma and abundance of siliceous microfossils except the core top from Hole 856B. The top of Hole $856 \mathrm{~B}$ contains only rare fragments of agglutinated taxa, and age indicators suggest a Pleistocene age. The sample is dominated by sinistral $N q$. pachyderma and has only rare, poorly preserved radio- 
Table 4. Estimated depths of Holocene-Pleistocene boundary.

\begin{tabular}{|c|c|c|c|c|c|}
\hline Hole & $\begin{array}{l}\text { Depth of } \\
\text { deepest } \\
\text { Holocene } \\
\text { sample } \\
\text { (mbsf) }\end{array}$ & $\begin{array}{c}\text { Depth of } \\
\text { shallowest } \\
\text { Pleistocene } \\
\text { sample } \\
\text { (mbsf) }\end{array}$ & $\begin{array}{c}\text { Depth of } \\
\text { H/P } \\
\text { boundary } \\
\text { (mbsf) }\end{array}$ & $\begin{array}{l}\text { Stratigraphic } \\
\text { error } \\
( \pm \mathrm{m})\end{array}$ & Presence of radiolarians, diatoms, and agglutinated taxa in core-top samples \\
\hline $855 \mathrm{~A}$ & 1.01 & 2.49 & 1.75 & 0.74 & $\begin{array}{l}\text { Radiolarians, diatoms, Saccammima sp. A, Ammodiscus, Saccammina sp. B, Haplophragmoides, Reophax, orange } \\
\text { tubes, thick-wall tubes }\end{array}$ \\
\hline $855 \mathrm{C}$ & 0.90 & 2.06 & 1.48 & 0.58 & Radiolarians, diatoms, Reophax sp. B, rare agglutinated tubes, thick-wall tubes \\
\hline $856 \mathrm{~A}$ & 0.00 & 0.92 & 0.46 & 0.46 & $\begin{array}{l}\text { Radiolarians, diatoms, flattened Haplophragmoides, Ammodiscus, Reophax sp. B, Saccammina sp. A, Reophax, } \\
\text { Eggerella, orange tubes, thick-wall tubes }\end{array}$ \\
\hline $856 \mathrm{~B}$ & & 0.00 & & & $\begin{array}{l}\text { Rust stained radiolarians, rare fragments of Ammodiscus, Reophax, Saccammina sp. A, flattened } \\
\text { Haplophragmoides, orange tube, thick-wall tube }\end{array}$ \\
\hline $857 \mathrm{~A}$ & $1.91(?)$ & $2.70(?)$ & $2.31(?)$ & 0.40 & Very rare radiolarians, no agglutinated specimens found \\
\hline $857 \mathrm{~B}$ & 0.81 & 1.68 & 1.25 & 0.43 & Radiolarians, diatoms, organic material, Saccammina sp. A, Reophax sp. B \\
\hline $857 \mathrm{C}$ & 0.62 & 1.67 & 1.15 & 0.53 & $\begin{array}{l}\text { Radiolarians, diatoms, organic material, flattened Haplophragmoides, Reophax sp. A, Reophax sp. B, } \\
\text { Ammodiscus fragment, Saccammina fragment, other rare agglutinated genera, orange tubes, thick-wall tubes }\end{array}$ \\
\hline $858 \mathrm{~A}$ & 0.00 & 0.49 & 0.25 & 0.25 & Radiolarians, diatoms, clay lumps, Reophax, Eggerella, Ammodiscus, orange tubes \\
\hline $858 \mathrm{~B}$ & Barren & 0.90 & $0.45(?)$ & 0.45 & Anhydrite \\
\hline $858 \mathrm{C}$ & 0.00 & 1.21 & 0.61 & 0.61 & $\begin{array}{l}\text { Radiolarians, diatoms, clay lumps, Ammodiscus, Saccammina sp. A, Reophax, Eggerella, Cribrostomoides, } \\
\text { orange tubes, other tubes }\end{array}$ \\
\hline 858D & Barren & 2.11 & $1.06(?)$ & 1.06 & $\begin{array}{l}\text { Radiolarians, diatoms, clay lumps, Ammodiscus, Saccammina sp. A, Reophax, Cribrostomoides, } \\
\text { Haplophragmoides, orange tubes, other tubes }\end{array}$ \\
\hline
\end{tabular}

larians. The apparent unconformity at the top of this hole is supported by the paleomagnetic data.

Two remaining topmost samples have special problems. One top sample (857A) has dextral $N q$. pachyderma and is Holocene or latest Pleistocene in age (younger than 14,000 yr), but contains few radiolarians and no agglutinated foraminifers, indicating that it probably is older than $7000 \mathrm{yr}$ (Karlin et al., 1992). This sample is probably from the subsurface as a result of overpenetration during initial coring. The sample was reassigned to a depth of $1.91 \mathrm{mbsf}$ based on operational criteria (see "Operations" section, "Site 857" chapter, Davis, Mottl, and Fisher, 1992). The age of the last core top (858B) is uncertain because the surficial hydrothermal sediment is barren of planktonic foraminifers.

The Holocene-Pleistocene boundary was tentatively placed in 8 of 11 holes based on the coiling ratio of sinistral and dextral Nq. pachyderma (Table 4). I have assumed that the base of the coiling shift to dextral Nq. pachyderma at the tops of the holes occurred $11,000 \mathrm{yr}$ ago (Bandy, 1960) at the regional Holocene-Pleistocene boundary. The boundary, however, cannot be placed at three holes because Holoceneage sediments are absent. Pleistocene-age sediments outcrop at the surface of Hole 856B. Pleistocene fossils occur below samples barren of planktonic foraminifers at Holes 858B and 858D.

\section{Pre-Holocene Interglacial Assemblages}

The coiling ratio of $\mathrm{Nq}$. pachyderma was examined in the preHolocene sequences of Holes 856A and 857A (Fig. 4; Tables 1 and 2). Most of the 103 foraminifer-rich samples at both holes have frequencies of sinistral Nq. pachyderma greater than $95 \%$. An unusual sample of abundant recrystallized planktonic foraminifers from $375 \mathrm{mbsf}$ in Hole $857 \mathrm{C}$ has a similarly high ratio of sinistral $\mathrm{Nq}$. pachyderma.

Several intervals bear more than $10 \%$ dextral forms of the species. An interval of seven samples at Hole 856A contains the dextral form ( $88 \%$ to $11 \%$ sinistral forms) from $16.77 \pm 0.84$ to $20.06 \pm 0.56 \mathrm{mbsf}$ (Fig. 4). The samples (Fig. 5) also contain high frequencies of Turborotalita quinqueloba and species from the transitional watermass, including Globorotalia hirsuta, Globorotalia inflata, Globigerinoides ruber, Globoturborotalita rubescens, Turborotalita humilis, Tenuitella iota, and Orbulina universa. Only one of the seven samples is clearly turbiditic (Sample 856A-3H-5, 108-110 cm), and the others are probably hemipelagic (Table 1) based on sand content, lithology, and constituents of the sand-size fraction. Two intervals bear dextral forms at Hole 857A (Fig. 4): (1) one sample bearing 78\% sinistral forms lies at $26.89 \mathrm{mbsf}$ and (2) nine samples with $8 \%$ to $81 \%$ sinistral forms lie between $36.16 \pm 0.17$ and $40.37 \pm 0.21$ mbsf. The depositional style of the first interval is ambiguous (Table 2) and will be discussed in a later section. The second interval (Fig. 6) also contains high frequencies of Turborotalita quinqueloba and species from the transitional watermass including Globorotalia hirsuta, Globorotalia inflata, Globigerinoides ruber, Globoturborotalita rubescens, Turborotalita humilis, Tenuitella iota, and Orbulina universa. Five of the nine samples are turbiditic and four are probably hemipelagic (Table 2) based on sand content, lithology, and constituents of the sandsize fraction.

An unusual sample of abundant recrystallized planktonic foraminifers is preserved at $375 \mathrm{mbsf}$ in Hole $857 \mathrm{C}$. The assemblage consists of $47 \%$ sinistral $\mathrm{Nq}$. pachyderma, $2 \%$ dextral $\mathrm{Nq}$. pachyderma, $20 \%$ Globigerina bulloides, $2 \%$ Globigerinita glutinata, and $29 \%$ indeterminate specimens that could not be identified due to their poor preservation state.

\section{Paleoenvironmental Analysis}

The census of planktonic foraminifers in the 103 samples that contain abundant tests from Holes $856 \mathrm{~A}$ and $857 \mathrm{~A}$ tabulates species typi$\mathrm{cal}$ of well-preserved assemblages from cool temperate to subpolar water masses (Table 6). Twenty-one taxa are listed, including sinistral $\mathrm{Nq}$. pachyderma, Globigerina bulloides, Turborotalita quinqueloba, Globigerinita glutinata, Globigerinita uvula, Globigerinita cf. uvula, Globigerinita minuta, dextral Nq. pachyderma, Orbulina universa, Tenuitella iota, Tenuitella parkerae, Globorotalia scitula, Globorotalia sp. A, a juvenile, nonencrusted sinistral $\mathrm{Nq}$. pachyderma, Globorotalia theyeri, Globigerina falconensis, Globorotalia inflata, Globorotalia hirsuta, Globigerinoides ruber, Globoturborotalita rubescens, Turborotalita humilis, and indeterminate specimens (Table 6, and "Taxonomic Notes" section, this chapter). The first seven taxa are common (Figs. 5 and 6) and the latter taxa are infrequent. In all subsequent discussions, Globigerinita uvula, Globigerinita $\mathrm{cf}$. uvula, and Globigerinita minuta are considered one counting group called Globigerinita uvula (see "Taxonomic Notes" section, this chapter).

Inspection of Figures 7 and 8 shows several distinctive trends. On average, samples from Hole $856 \mathrm{~A}$ have $17 \%$ more sinistral Nq. pachyderma and fewer Ga. bulloides, Tr. quinqueloba, and Gt. uvula than those from Hole 857A. At Hole 856A, sinistral Nq. pachyderma increase in relative frequency below 22 mbsf while frequencies of $G a$. bulloides and $T r$ : quinqueloba decrease. This effect occurs $4 \mathrm{~m}$ below the shallowest occurrence of carbonate concretions and $2 \mathrm{~m}$ below the shallowest common occurrence of calcite overgrowths on foraminif- 
Table 5. Selection of Holocene-Pleistocene boundaries.

\begin{tabular}{|c|c|c|c|c|c|c|}
\hline $\begin{array}{l}\text { Core, section, } \\
\text { interval }(\mathrm{cm})\end{array}$ & $\begin{array}{l}\text { Depth } \\
\text { (mbsf) }\end{array}$ & $\mathrm{Tl}$ & Pdl & Pdr & Coil & Age \\
\hline \multicolumn{7}{|l|}{$139-855 \mathrm{~A}-$} \\
\hline $1 \mathrm{R}-1,0-1$ & 0.00 & 30 & 23 & 7 & 77 & Holocene \\
\hline $1 R-1,100-102$ & 1.00 & 30 & 25 & 5 & 83 & Holocene \\
\hline $1 \mathrm{R}-2,98-100$ & 2.48 & 31 & 31 & 0 & 100 & Pleistocene \\
\hline 1R-3, 102-104 & 4.02 & 30 & 30 & 0 & 100 & Pleistocene \\
\hline $1 \mathrm{R}-4,102-104$ & 5.52 & 30 & 28 & 2 & 93 & Pleistocene \\
\hline 1R-5, 71-73 & 6.71 & 30 & 30 & 0 & 100 & Pleistocene \\
\hline IR-CC & 7.60 & 31 & 26 & 5 & 84 & Turbidite \\
\hline $2 \mathrm{R}-1,118-120$ & 8.78 & 0 & 0 & 0 & & Barren \\
\hline $2 \mathrm{R}-2,138-140$ & 10.48 & 30 & 30 & 0 & 100 & Pleistocene \\
\hline $2 \mathrm{R}-3,118-120$ & 11.78 & 0 & 0 & 0 & & Barren \\
\hline $2 R-4,60-62$ & 12.70 & 0 & 0 & 0 & & Barren \\
\hline $2 \mathrm{R}-5,56-60$ & 14.16 & 30 & 30 & 0 & 100 & Pleistocene \\
\hline 2R-CC & 16.60 & 30 & 28 & 2 & 93 & Pleistocene \\
\hline \multicolumn{7}{|l|}{ 139-855C- } \\
\hline $1 \mathrm{R}-1,0-1$ & 0.00 & 30 & 27 & 3 & 90 & Holocene(?) \\
\hline 1R-1, 89-91 & 0.89 & 30 & 25 & 5 & 83 & Holocene \\
\hline IR-2, 55-57 & 2.05 & 30 & 29 & 1 & 97 & Pleistocene \\
\hline 1R-3, $90-92$ & 3.90 & 30 & 30 & 0 & 100 & Pleistocene \\
\hline IR- $4,92-94$ & 5.42 & 30 & 30 & 0 & 100 & Pleistocene \\
\hline 1R-5, 92-94 & 6.92 & 30 & 28 & 2 & 93 & Pleistocene \\
\hline IR- $6,79-81$ & 8.29 & 0 & 0 & 0 & & Barren \\
\hline IR-CC & 8.70 & 31 & 30 & 1 & 97 & Pleistocene \\
\hline \multicolumn{7}{|l|}{ 139-856A- } \\
\hline $1 \mathrm{H}-1,0-1$ & 0.00 & 75 & 64 & 11 & 85 & Holocene \\
\hline $1 \mathrm{H}-1,91-93$ & 0.91 & 58 & 56 & 2 & 97 & Pleistocene \\
\hline $1 \mathrm{H}-2,48-50$ & 1.68 & 140 & 136 & 4 & 97 & Pleistocene \\
\hline $2 \mathrm{H}-2,90-92$ & 5.10 & 201 & 199 & 2 & 99 & Pleistocene \\
\hline \multicolumn{7}{|l|}{ 139-856B- } \\
\hline $1 \mathrm{H}-1,0-1$ & 0.00 & 30 & 30 & 0 & 100 & Pleistocene \\
\hline $1 \mathrm{H}-1,89-91$ & 0.89 & 30 & 28 & 2 & 93 & Pleistocene \\
\hline \multicolumn{7}{|l|}{$139-857 \mathrm{~A}-$} \\
\hline $1 \mathrm{H}-1,0-1$ & 1.90 & 114 & 97 & 17 & 85 & Holocene \\
\hline $1 \mathrm{H}-1.79-81$ & 2.69 & 149 & 144 & 5 & 97 & Pleistocene \\
\hline $1 \mathrm{H}-2,125-129$ & 4.65 & 152 & 150 & 2 & 99 & Pleistocene \\
\hline $1 \mathrm{H}-3,10-13$ & 5.00 & 94 & 94 & 0 & 100 & Pleistocene \\
\hline \multicolumn{7}{|l|}{ 139-857B } \\
\hline $1 \mathrm{H}-1,0-1$ & 0.00 & 30 & 18 & 12 & 60 & Holocene \\
\hline $1 \mathrm{H}-1,80-82$ & 0.80 & 30 & 25 & 5 & 83 & Holocene \\
\hline $1 \mathrm{H}-2,17-19$ & 1.67 & 30 & 29 & 1 & 97 & Pleistocene \\
\hline $1 \mathrm{H}-3,10-12$ & 3.10 & 30 & 30 & 0 & 100 & Pleistocene \\
\hline \multicolumn{7}{|l|}{ 139-857C- } \\
\hline IR-1, 0-1 & 0.00 & 30 & 13 & 17 & 43 & Holocene \\
\hline IR-1, 61-65 & 0.61 & 30 & 22 & 8 & 73 & Holocene \\
\hline IR-2, 16-18 & 1.66 & 30 & 29 & 1 & 97 & Pleistocene \\
\hline IR-3, 31-33 & 3.31 & 0 & 0 & 0 & & Barren \\
\hline 1R-CC & 3.40 & 30 & 28 & 2 & 93 & Pleistocene \\
\hline \multicolumn{7}{|l|}{ 139-858A- } \\
\hline $\begin{array}{l}1 \mathrm{H}-1,0-1 \\
1 \mathrm{H}-1,48-50\end{array}$ & $\begin{array}{l}0.00 \\
0.48\end{array}$ & $\begin{array}{l}30 \\
30\end{array}$ & $\begin{array}{l}18 \\
26\end{array}$ & $\begin{array}{r}12 \\
4\end{array}$ & $\begin{array}{l}60 \\
87\end{array}$ & $\begin{array}{l}\text { Holocene } \\
\text { Pleistocene }\end{array}$ \\
\hline $\begin{array}{l}\text { 1H-1,48-50 } \\
1 \mathrm{H}-\mathrm{CC}\end{array}$ & 2.40 & 31 & 31 & 0 & 100 & $\begin{array}{l}\text { Plesstocene } \\
\text { Pleistocene }\end{array}$ \\
\hline \multicolumn{7}{|l|}{ 139-858B- } \\
\hline $1 \mathrm{H}-1,0-1$ & 0.00 & 0 & 0 & 0 & & Barren \\
\hline $1 \mathrm{H}-1,89-93$ & 0.89 & 30 & 30 & 0 & 100 & Pleistocene \\
\hline \multicolumn{7}{|l|}{$139-858 \mathrm{C}-$} \\
\hline $1 \mathrm{H}-1,0-1$ & 0.00 & 37 & 28 & 9 & 76 & Holocene \\
\hline $1 \mathrm{H}-1,120-124$ & 1.20 & 31 & 30 & 1 & 97 & Pleistocene \\
\hline \multicolumn{7}{|l|}{ 139-858D- } \\
\hline $1 \mathrm{H}-1,0-1$ & 0.00 & 0 & 0 & 0 & & Barren \\
\hline $1 \mathrm{H}-1,37-41$ & 0.37 & 0 & 0 & 0 & & Barren \\
\hline $1 \mathrm{H}-2,60-64$ & 2.10 & 30 & 30 & 0 & 100 & Pleistocene \\
\hline
\end{tabular}

Notes: $\mathrm{Tl}=$ total number of specimens counted; $\mathrm{Pdl}=$ number of sinistral Neogloboquadrina pachyderma counted; $\mathrm{Pdr}=$ number of dextral Neogloboquadrina pachyderma counted; Coil $=$ coiling ratio $(100 \cdot \mathrm{Pdl} / \mathrm{Tl})$.

eral tests. Hole 856A also has more indeterminate species than Hole $857 \mathrm{~A}$, an effect which is in part due to the calcite overgrowths on foraminiferal tests.

Q-mode cluster analysis (Tables 7, 8, and 9; Fig. 9) resolves three major groups of samples, Cluster 1 with 34 samples that contain more than $43 \%$ sinistral $N q$. pachyderma and lower frequencies of other species; Cluster 2 with six samples that contain very low frequencies $(<4 \%)$ of sinistral Nq. pachyderma, significant frequencies of dextral
Nq. pachyderma, Gt. glutinata, and transitional species, and high frequencies of $\operatorname{Tr}$. quinqueloba; and Cluster 3 with 63 samples that contain $41 \%$ to $7 \%$ sinistral $N q$. pachyderma. Clusters 1 and 3 are further divided into subclusters. Cluster 1 has two subclusters, a and $\mathrm{b}$, distinguished primarily by higher and lower frequencies of sinistral $\mathrm{Nq}$. pachyderma. Cluster 3 is divided into three subclusters, a, b, and c. Subcluster $3 \mathrm{a}$ has the most equitable distribution of frequencies among sinistral Nq. pachyderma, Tr: quinqueloba, and Gt. uvula. Subcluster $3 \mathrm{~b}$ has moderate frequencies of Tr. quinqueloba and sinistral $\mathrm{Nq}$. pachyderma and relatively low frequencies of Gt. uvula. Subcluster $3 \mathrm{c}$ has high frequencies of Gt. uvula, moderate frequencies of sinistral $\mathrm{Nq}$. pachyderma, and fairly low frequencies of $\mathrm{Tr}$. quinqueloba.

Correlation analysis supports the relationships discussed above (Table 10). Frequencies of six of the seven taxonomic groups show some correlations with other groups. Sinistral $N q$. pachyderma correlates negatively with $T r$. quinqueloba, Gt. uvula, and Gt. glutinata. Dextral $N q$. pachyderma correlates positively with Gt. glutinata and the transitional species and negatively with Gt. uvula. Gt. glutinata correlates positively with the transitional species. These relationships are seen in the cluster associations. Relative frequencies of $\mathrm{Ga}$. bulloides, however, do not correlate significantly with those of any other species and play no clear role in clustering the samples.

At Hole 856A (Figs. 7 and 8), Cluster 1 dominates faunas below 22 mbsf within the zone of calcite precipitation, but does not dominate below the shallowest occurrence of diagenetic carbonate $(46.05$ mbsf) at Hole 857A. Cluster 2 dominates at one discrete interval in each of Holes 856A and 857A. Cluster 3 dominates throughout the remainder of the fossil-rich sequences.

\section{DISCUSSION \\ Biostratigraphy}

The intervals of sinistral and dextral coiling of $\mathrm{Nq}$. pachyderma were used to subdivide the fossil-rich sequences in Hole $856 \mathrm{~A}$ and $857 \mathrm{~A}$ (Fig. 4). The surficial interval bearing dextral forms of the species is tentatively called coiling direction zone 1 ; the underlying interval of $>90 \%$ sinistral forms, coiling direction zone 2 ; the underlying interval dominated by the dextral form, coiling direction zone 3 ; and the underlying interval of $>90 \%$ sinistral forms, coiling direction zone 4. The intervals from 16.77 to $20.06 \mathrm{mbsf}$ at Hole $856 \mathrm{~A}$ and the interval from 36.16 to $40.37 \mathrm{mbsf}$ at Hole $857 \mathrm{~A}$ are tentatively correlated and assigned to coiling direction zone 3 based on the similarity of their assemblages. The samples cluster together in the cluster analysis (Table 7. Cluster 2) based on the most common species. Inspection of the species present from the transitional and subtropical water masses again shows great similarities (Table 6; Figs. 5 and 6).

Hole $857 \mathrm{~A}$ has one other subsurface "interval" of dextral coiling forms (78\% sinistral forms) represented by Sample 857A-4H-4, 49-51 $\mathrm{cm}$, from $26.89 \mathrm{mbsf}$ (Fig. 4). The samples from $10 \mathrm{~cm}$ below and 8 $\mathrm{cm}$ above have $100 \%$ and $90 \%$ sinistrally coiled forms, respectively. The sample is unusual compared with others in the data set (Fig. 6); it contains the highest frequency of $G a$. bulloides, and it does not cluster stably when other amalgamation methods are used. It has the fifth highest benthic foraminiferal frequency, and it was taken from the top of a fining upward sequence. The unusual sample is excluded from biostratigraphic assignment.

Two datums were tentatively recognized at Holes 856A and 857A: the base of the Holocene and the base of the penultimate interglacial period (= base of Oxygen Isotope Stage 5). I assume that the base of coiling direction zone 1 marks the base of the Holocene at about 11,000 yr ago in the North Pacific Ocean (Bandy, 1960). Please note that the assumption may be incorrect and is presently under study (see "Biostratigraphy of the Northeast Pacific Ocean" section, this chapter). The depths of the Holocene-Pleistocene boundary (Table 4) range from a minimum of less than 0.49 mbsf at Site 858 to a maximum between 0.81 and $2.49 \mathrm{mbsf}$ at the other sites, discounting Hole 857A, at which 


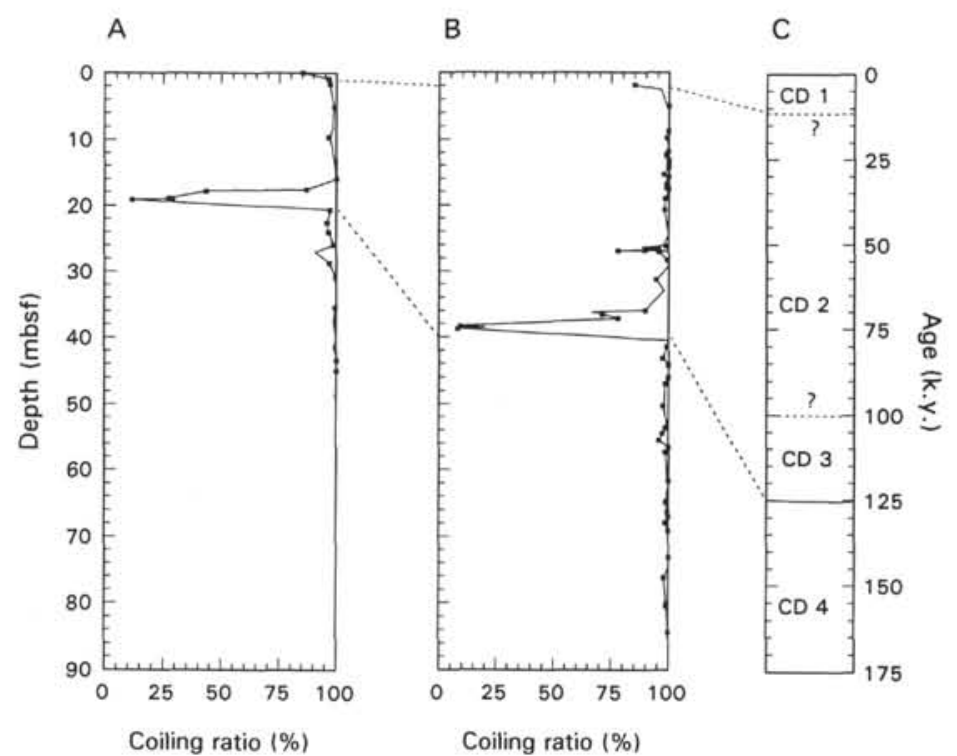

Figure 4. Coiling ratios of samples in (A) Hole 856A and (B) Hole $857 \mathrm{~A}$ measured as the frequency of sinistral Neogloboquadrina pachyderma (Ehrenberg) relative to both sinistral and dextral forms. Hemipelagic(?) samples are flagged by filled squares; turbiditic samples have no symbol. The cores are correlated by dashed lines to informal coiling direction zones $(\mathbf{C})$.
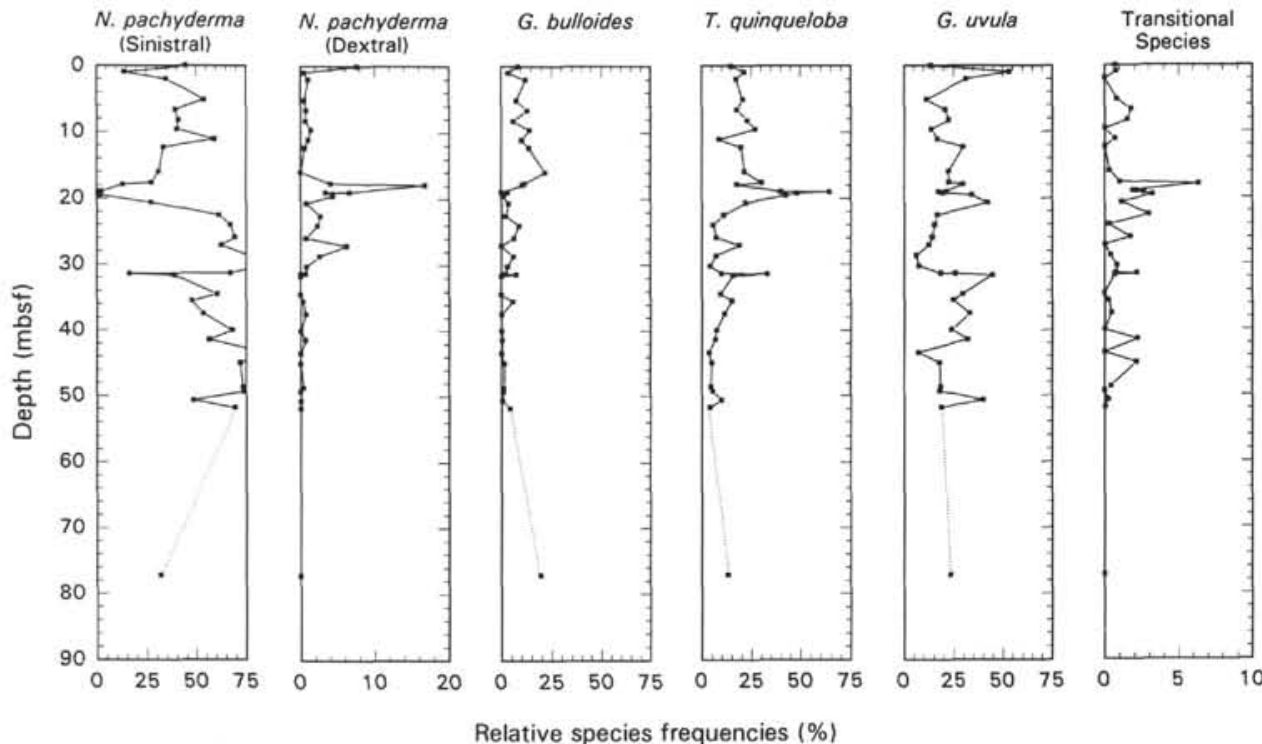

Figure 5. Relative frequencies (\%) of six common taxa at Hole 856A plotted with depth in hole (mbsf).

there were operational difficulties that make the true depth uncertain and Hole $856 \mathrm{~B}$ where the uppermost part of the section was eroded. The depths of the boundary at Sites $855,856 \mathrm{~A}$, and 857 are not significantly different due to the coarse sampling interval (see Table 4 , "Stratigraphic error" column). The average depth of the boundary is $0.94 \pm 0.50 \mathrm{~m}$ and the average sedimentation rate for the Holocene at Leg 139 sites is $9 \pm 4 \mathrm{~cm} / \mathrm{k}$.y., which is comparable to the rate of 11.5 $\mathrm{cm} / \mathrm{k} . \mathrm{y}$. determined by Al-Aasm and Blaise (1991) for one core in Middle Valley, the average rate of $14 \pm 4 \mathrm{~cm} / \mathrm{k} . \mathrm{y}$. estimated in Escanaba Trough (Karlin and Lyle, 1986), and the rate of $10 \mathrm{~cm} / \mathrm{k} . \mathrm{y}$. estimated in intercanyon areas of Astoria Fan (Nelson et al., 1968). Differences in sedimentation rates, however, should be regarded with caution because differences in sampling methods can cause differences in plastic compaction and extension during coring.

I assume that the base of the coiling direction zone 3 marks the base of the penultimate interglacial period (= Oxygen Isotope Stage 5$)$ at $125,000 \mathrm{yr}$ ago. The sedimentation rate from the Holocene-Pleistocene boundary to this datum is $17 \mathrm{~cm} / \mathrm{k}$.y. at Hole $856 \mathrm{~A}$ and $33 \mathrm{~cm} / \mathrm{k} . \mathrm{y}$. at Hole $857 \mathrm{~A}$ (Table 11). These rates are similar to the average Pleisto- cene rate calculated on Astoria Fan at Deep Sea Drilling Project Site 174. The interval between the datum levels at Hole 856A lies almost entirely in Lithologic Subunit IIA, so the sedimentation rate may be relatively constant throughout the interval. The interval between the datum levels at Hole 857 A lies both in Lithologic Unit I and Lithologic Subunit IIA, which contains more frequent and coarser turbidites than the overlying unit. The sedimentation rate is probably faster below the lithologic boundary at $25.20 \mathrm{mbsf}$. The lithologic boundary probably marks the age of an uplift event at the section. The age from simple interpolation suggests that this event occurred between 80,000 and 125,000 yr ago.

The ages of the bases of the fossil-rich intervals were estimated at Hole $856 \mathrm{~A}$ and $857 \mathrm{~A}$. The accuracy of the extrapolation is highly suspect, but it does provide maximum expected ages of $302,000 \mathrm{yr}$ at Hole 856 A and 248,000 yr at Hole 857A. (For comparison, the estimated age of basement is 320,000 and $250,000 \mathrm{yr}$, respectively, at Holes 856A and 857A.) If the extrapolated ages were correct, then the fossil-rich sequences should each contain an additional interglacial fauna from the base of Oxygen Isotope Stage 7 from 240,000 yr ago. 

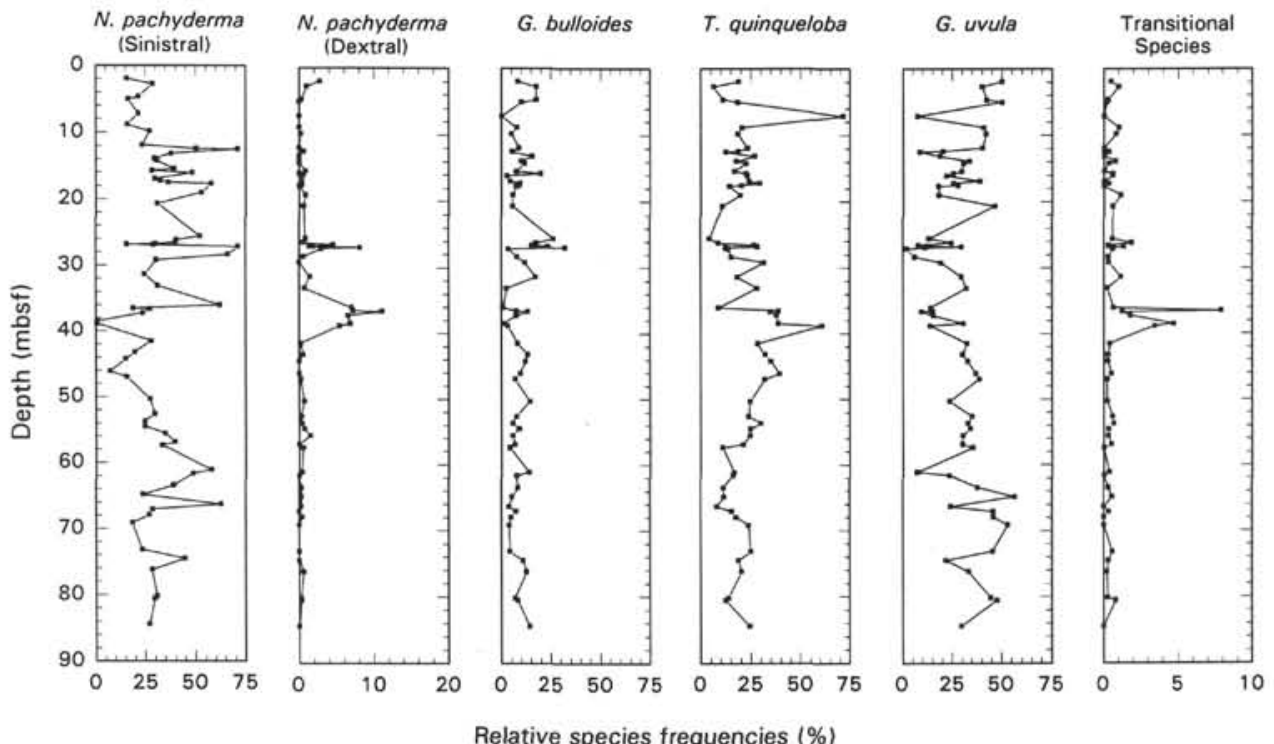

Figure 6. Relative frequencies (\%) of six common taxa at Hole 857A plotted with depth in hole (mbsf).
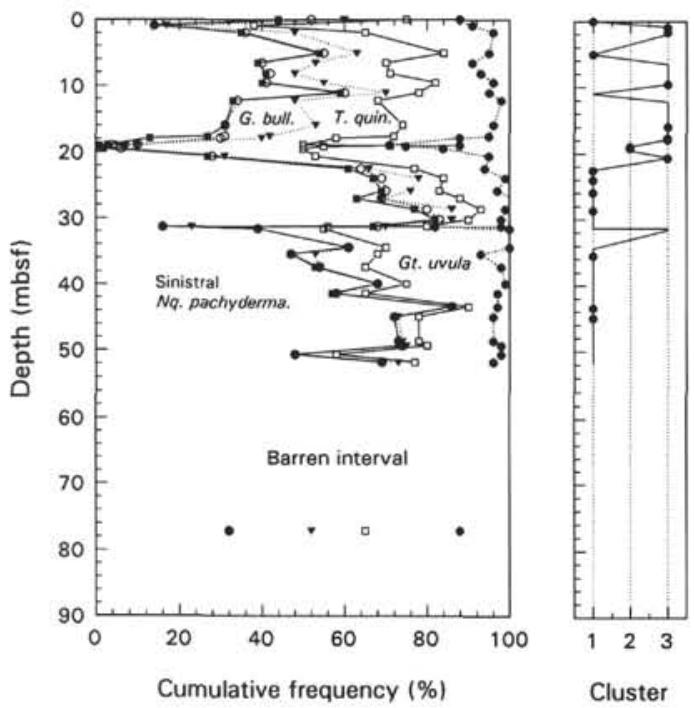

Figure 7. Cumulative frequencies (\%) of four common taxa (left graph) and clusters from Q-mode analysis (right graph) plotted with depth (mbsf) at Hole 856A. The four common taxa are sinistral Neogloboquadrina pachyderma, Globigerina bulloides, Turborotalita quinqueloba, and Globigerinita uvula. Cluster 1 includes all samples from the subarctic dissolution assemblage, Cluster 2 includes all samples from the transitional assemblage, and Cluster 3 includes all samples from the subarctic assemblage. In the right graph, hemipelagic(?) samples are flagged by filled circles and turbiditic samples have no symbol.

No such interval was found, but additional samples are presently under study. It is possible that a dextral coiling interval was missed during sampling. The observed dextral intervals span 2.21 and 4.21 $\mathrm{m}$ in Holes $856 \mathrm{~A}$ and $857 \mathrm{~A}$, respectively, and sampling intervals average $1.55 \mathrm{~m}$ in Hole $856 \mathrm{~A}$ and $1.09 \mathrm{~m}$ in Hole $857 \mathrm{~A}$. Therefore, a dextral coiling shift shorter than these sampling intervals would be entirely missed.

The sedimentary sequences below 85 mbsf at most Leg 139 holes were mostly barren or depleted of fossils and could not be zoned. One fossil-rich sample, though highly recrystallized, was recovered from $375 \mathrm{mbsf}$ in Hole $857 \mathrm{C}$ (857C-40R-CC). The sample bears an assem-

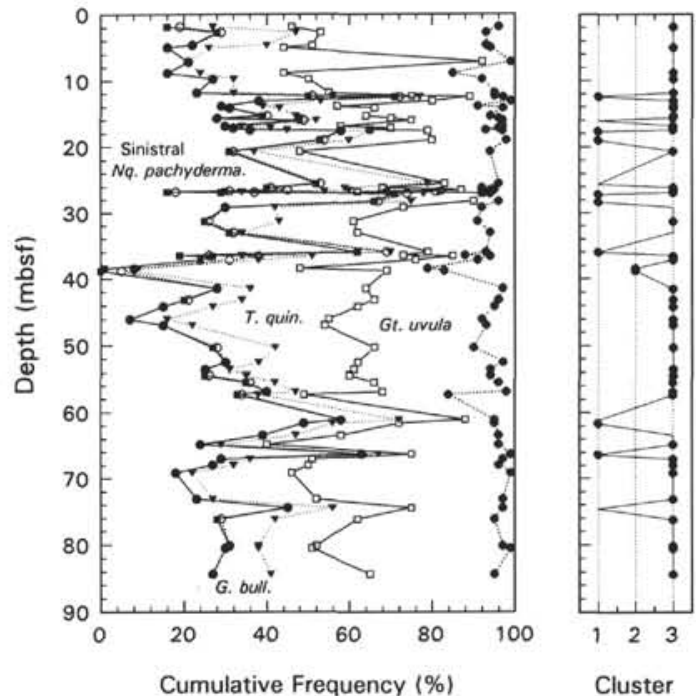

Figure 8. Cumulative frequencies (\%) of four common taxa (left graph) and clusters from Q-mode analysis (right graph) plotted with depth (mbsf) at Hole 857A. The four common taxa are sinistral Neogloboquadrina pachyderma, Globigerina bulloides, Turborotalita quinqueloba, and Globigerinita uvula. Cluster 1 includes all samples from the subarctic dissolution assemblage, Cluster 2 includes all samples from the transitional assemblage, and Cluster 3 includes all samples from the subarctic assemblage. In the right graph, hemipelagic(?) samples are flagged by filled circles and turbiditic samples have no symbol.

blage that is consistent with cold-water faunas of the last $0.6 \mathrm{Ma}$ in the subarctic Pacific Ocean (Lagoe and Thompson, 1988).

\section{Paleoenvironment}

The assemblages defined by cluster analysis are typical of the transitional and subpolar plankton assemblages (Bradshaw, 1959) that have been modified by dissolution (Coulbourn et al., 1980; Sautter and Thunell, 1989; 1991). Cluster 1 (Fig. 9) is dominated by sinistral $N q$. pachyderma and is typical of subpolar assemblages modified by dissolution so that delicate species have been removed (Sautter and Thunell, 



Figure 9. Average species composition of each subcluster from the Q-mode cluster analysis of samples (Table 8). The standard deviation for each species average is shown by the error bars. The subarctic dissolution assemblage (Cluster 1) is marked by an intermediate diagonal line, the transitional assemblage (Cluster 2) is marked by the fine diagonal line, and the subarctic assemblage (Cluster 3 ) is marked by a coarse diagonal line. Abbreviations are as in Table 8.

$1989 ; 1991)$. This is consistent with the fact that most of the samples in the cluster come from the zone of calcite overgrowths in Hole $856 \mathrm{~A}$. Some of the delicate forms apparently were removed by postdepositional calcite mobilization. These assemblages are similar to those at Hole 857A which lie both above and below the depth of the first diagenetic carbonate at $46.05 \mathrm{mbsf}$. The assemblages altered by overgrowths are indistinguishable in species content from those dissolved by ordinary postdepositional processes.

Cluster 2 (Fig. 9) is typical of a transitional assemblage with more dextral than sinistral $\mathrm{Nq}$. pachyderma and the common occurrence of other subpolar species. Compared to the rest of the data set, the samples have the most abundant frequencies of dextral $\mathrm{Nq}$. pachyderma, $\mathrm{Tr}$. quinqueloba, and Gt. glutinata, species which undergo maximum production together at times of maximum oceanic fertility (Sautter and Thunell, 1991). Maximum production of Tr: quinqueloba, in particular, is associated with spring bloom conditions (Sautter and Sancetta. 1992). Proximity to the subarctic boundary is suggested by small but significant occurrences of cool subtropical taxa such as Globorotalia hirsuta, Globorotalia inflata, Globigerinoides ruber, and Globoturborotalita rubescens. The assemblage also appears fairly well preserved based on the large numbers of delicate species relative to robust $\mathrm{Nq}$. pachyderma and based on planktonic foraminiferal numbers that are not significantly different from those of the glacial faunas.

Cluster 3 (Fig. 9) is typical of subarctic assemblages that are better preserved than those of Cluster 1 (Sautter and Thunell, 1989). The assemblage has significantly more delicate species and fewer of the robust sinistral $\mathrm{Nq}$. pachyderma than Cluster 1 . It is unclear whether the dominance of Tr: quinqueloba (Cluster 3b), Gt. uvula (Cluster 3c), or the more equitable preservation of both these species with $G a$. bulloides (Cluster $3 \mathrm{a}$ ) is controlled by environment of the water mass (changes in upwelling [Lyle et al., 1992], freshening [Sancetta, 1979], or cooling [Moore et al., 1980] of surface waters as discussed in the "Pleistocene Paleoenvironmental History" section, this chapter), or by postdepositional dissolution.

The species Globigerina bulloides occurs in both high and low frequencies in most of the subclusters. The species has wide environmental tolerances, thrives in water masses from subtropical to subpolar regions, and reaches peaks of production during upwelling events (Sautter and Thunell, 1991; Sautter and Sancetta, 1992). The tests are also very susceptible to dissolution (Sautter and Thunell, 1989; 1991), and their frequency may be sensitive to postdepositional processes. For all of these reasons, it is not surprising that the species does not correlate with any other subarctic species and does not aid clustering of samples.

The patterns of clusters with depth in hole (Figs. 7 and 8) map out several environmental events:

1. The appearance of the transitional assemblage (Cluster 2) at the Leg 139 sites suggests that transitional waters in proximity to the subpolar boundary migrated to this locality at least once during the late Pleistocene. I tentatively correlate the migration to the penultimate interglacial period $125,000 \mathrm{yr}$ ago.

2. In general, well-preserved assemblages of subarctic foraminifers (Cluster 3 ) occur above $22 \mathrm{mbsf}$ at Hole $856 \mathrm{~A}$ and throughout Hole $857 \mathrm{~A}$ with sporadic occurrences of the dissolution subarctic assemblage (Cluster 1). The distributions of these assemblages reflect the position of the regional CCD. The regional CCD lay below Leg 139 sites throughout most of the two late Pleistocene glacial periods observed at the study site. It is unclear whether the sporadic occurrences of the dissolution assemblage in well-preserved intervals is related to brief rises of the CCD (Karlin et al., 1992). The dissolution assemblage dominates samples below $22 \mathrm{mbsf}$ at Hole 856A and reflects a zone of calcite precipitation driven by hydrothermal alteration.

3. The specimens in coiling direction zone CD 3 (penultimate interglacial period) appear fairly well preserved, indicating that the CCD did not rise above the sites at about $2400 \mathrm{~m}$ water depth as the $\mathrm{CCD}$ did not rise above the sites during the present interglacial period.

\section{CONCLUSIONS}

1. The late Quaternary sequences were divided into four informal coiling direction zones numbered from the top to the bottom of the fossil-rich sections. Coiling direction zones 1 and 3 contain fewer than $90 \%$ sinistrally coiled forms of $\mathrm{Nq}$. pachyderma and coiling direction zones 2 and 4 contain more than $90 \%$ sinistrally coiled forms.

2. Coiling direction zones 1 and 3 correspond approximately to interglacial intervals: a Holocene interval at the tops of Holes $856 \mathrm{~A}$ and $857 \mathrm{~A}$ and a penultimate interglacial interval with bases at approximately 20 and $40 \mathrm{mbsf}$ in Holes $856 \mathrm{~A}$ and $857 \mathrm{~A}$, respectively. The bases of these intervals are tentatively assigned ages of 11,000 and $125,000 \mathrm{yr}$ ago.

3. The census data of Pleistocene planktonic foraminifers cluster into three main groupings: (1) a subarctic dissolution assemblage from which delicate forms have been dissolved, (2) a transitional assemblage with species characteristic of transitional waters which presently lie south of Leg 139 sites, and (3) a subarctic assemblage with 3 subclusters which reflect differences either in surface-water environment or postdepositional dissolution.

4. Foraminifers below $22 \mathrm{mbsf}$ at Hole $856 \mathrm{~A}$ are covered by calcite overgrowths and the assemblage has been modified by removal of delicate species. Most samples in this interval belong to the subarctic dissolution assemblage, Cluster 1.

5. The interglacial interval is characterized by the transitional assemblage which suggests that the subpolar boundary migrated north- 
Table 6. Census (tests counted in a split of the sample) of planktonic foraminifers at Holes 856 A and 857 A.

\begin{tabular}{|c|c|c|c|c|c|c|c|c|c|c|c|c|c|c|c|c|c|c|c|c|c|c|c|c|c|c|c|c|}
\hline $\begin{array}{l}\text { Core, section, } \\
\text { interval }(\mathrm{cm})\end{array}$ & $\begin{array}{l}\text { Depth } \\
\text { (mbsf) }\end{array}$ & Split & SedWt & SandWt & Ben & Pla & Pdl & Pdr & Bul & Qui & Glu & Cfu & Uvu & Uni & lot & Par & Juv & Ind & Sci & Gra & Min & The & Fal & Inf & Hum & Rub & Hir & Rube \\
\hline \multicolumn{29}{|l|}{$139-856 \mathrm{~A}-$} \\
\hline $1 \mathrm{H}-1,0-1$ & 0.00 & 0.0939 & & & 188 & 144 & 64 & 11 & 12 & 21 & 7 & 11 & 3 & 1 & 0 & 0 & 0 & 9 & 0 & 0 & 5 & 0 & 0 & 0 & 0 & 0 & 0 & 0 \\
\hline 1H-1,91-93 & 0.91 & 0.0059 & 8.3919 & 0.1289 & 9 & 404 & 56 & 2 & 14 & 86 & 13 & 129 & 26 & 0 & 1 & 0 & 3 & 12 & 2 & 0 & 60 & 0 & 0 & 0 & 0 & 0 & 0 & 0 \\
\hline $1 \mathrm{H}-2,48-50$ & 1.68 & 0.0078 & 10.0561 & 0.1854 & 8 & 392 & 136 & 4 & 47 & 67 & 11 & 97 & 15 & 0 & 0 & 0 & 4 & 1 & 0 & 0 & 10 & 0 & 0 & 0 & 0 & 0 & 0 & 0 \\
\hline $2 \mathrm{H}-2,90-92$ & 5.10 & 0.1875 & 11.7541 & 0.0354 & 149 & 369 & 199 & 2 & 28 & 76 & 12 & 30 & 6 & 0 & 1 & 0 & 1 & 6 & 2 & 0 & 6 & 0 & 0 & 0 & 0 & 0 & 0 & 0 \\
\hline $2 \mathrm{H}-3,90-92$ & 6.60 & $\begin{array}{l}1.0000 \\
\end{array}$ & 13.5487 & 0.0085 & 23 & 292 & 114 & 2 & 37 & 51 & 17 & 39 & $\frac{0}{2}$ & 2 & $\begin{array}{l}1 \\
3\end{array}$ & 0 & 0 & 6 & 0 & 0 & $\begin{array}{l}0 \\
19\end{array}$ & $\begin{array}{l}0 \\
0\end{array}$ & 0 & 0 & 0 & 0 & 0 & $\begin{array}{l}0 \\
0\end{array}$ \\
\hline $2 \mathrm{H}-4,101-103$ & 21 & 0781 & 12.7467 & 0.05 & 72 & 337 & 137 & 2 & 19 & 77 & 8 & 51 & 9 & 0 & 0 & 0 & 0 & 14 & 3 & 0 & 15 & 0 & 0 & 0 & 2 & 0 & 0 & 0 \\
\hline $2 \mathrm{H}-5,86-88$ & 9.56 & 1875 & 11.9664 & 0.0310 & 275 & 295 & 118 & 4 & 41 & 79 & 10 & 25 & 6 & 0 & 0 & 0 & 1 & 2 & 0 & 0 & 9 & 0 & 0 & 0 & 0 & 0 & 0 & 0 \\
\hline $2 \mathrm{H}-6,86-88$ & 11.06 & 0.0234 & 11.6165 & 0.0703 & 15 & 308 & 182 & 3 & 31 & 26 & 8 & 37 & 7 & 0 & 0 & 0 & i & 3 & 1 & 0 & 8 & 0 & 0 & 0 & 1 & 0 & 0 & 0 \\
\hline $2 \mathrm{H}-7,56-58$ & 12.26 & 0.0313 & 9.7456 & 0.0828 & 8 & 588 & 195 & 3 & 80 & 115 & 14 & 168 & 0 & 0 & 0 & 0 & 0 & 7 & 0 & 0 & 6 & 0 & 0 & 0 & 0 & 0 & 0 & 0 \\
\hline $3 \mathrm{H}-2,90-95$ & 14.60 & 1.0000 & 13.4915 & 0.0079 & 0 & 0 & 0 & 0 & 0 & 0 & 0 & 0 & 0 & 0 & 0 & 0 & 0 & 0 & 0 & 0 & 0 & 0 & 0 & 0 & 0 & 0 & 0 & 0 \\
\hline $3 \mathrm{H}-3,72-74$ & 15.92 & 0.1250 & 14.1628 & 0.0234 & 34 & 327 & 101 & 0 & 71 & 70 & 7 & 67 & 2 & 0 & 0 & ( & 0 & 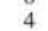 & 1 & 0 & 4 & 0 & 0 & 0 & 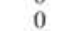 & 0 & 0 & 0 \\
\hline $3 \mathrm{H}-4,91-93$ & 17.61 & 0.0938 & 13.9345 & 0. & 28 & 297 & 81 & 12 & 34 & 90 & 7 & 33 & 0 & 0 & 0 & 0 & 0 & 3 & 3 & : & 34 & 0 & 0 & 0 & 0 & 0 & 0 & 0 \\
\hline $3 \mathrm{H}-4,1$ & 17.87 & 0.0469 & 12.6937 & 0. & 34 & 363 & $\begin{array}{l}011 \\
47\end{array}$ & 61 & 38 & 64 & 18 & 54 & 4 & 0 & 1 & 0 & 1 & 3 & 3 & 1 & 50 & 0 & 0 & 17 & 0 & 1 & 0 & 0 \\
\hline $3 \mathrm{H}-5,74-76$ & 18.94 & 0.1250 & 10.9087 & 9 & 117 & 317 & 8 & 21 & 0 & 127 & 30 & 47 & 15 & 0 & 0 & 22 & 17 & 18 & 0 & 0 & 6 & 0 & 0 & 1 & 0 & 5 & 0 & 0 \\
\hline $3 \mathrm{H}-5,78-80$ & 18.98 & 0.1250 & 9.82 & 0.0 & 75 & 50 & 7 & 17 & 16 & 327 & 29 & 69 & 3 & 0 & 1 & 0 & 0 & 13 & 10 & 0 & 16 & 0 & 0 & 0 & 0 & 0 & 0 & 0 \\
\hline $3 \mathrm{H}-5,96-98$ & 19.16 & 0.0781 & 11.6319 & 0.0562 & 47 & 346 & 2 & 15 & 6 & 167 & 25 & 37 & 10 & 0 & 2 & 17 & 17 & 20 & 2 & 2 & 21 & 0 & $\approx$ & 1 & 0 & 0 & 0 & 0 \\
\hline $3 \mathrm{H}-5,130-132$ & 19.20 & 0.0625 & 12.0175 & 0.0745 & 42 & 621 & 11 & 27 & 6 & 264 & 38 & 199 & 8 & 0 & 2 & ii & 18 & 13 & 1 & 0 & 6 & 0 & 0 & 0 & 13 & 2 & 1 & 1 \\
\hline $3 \mathrm{H}-6,92-94$ & 20.62 & 0.0039 & 11.7012 & 0.5064 & 38 & 539 & 146 & 4 & 18 & 118 & 8 & 134 & 2 & 0 & $=$ & 0 & 0 & 12 & 3 & 1 & 91 & 0 & & 0 & & 0 & 0 & 0 \\
\hline $3 \mathrm{H}-7,39-41$ & 21.59 & 1.0000 & 14.4733 & 0.0887 & 0 & 0 & 0 & 0 & 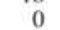 & mo & 0 & . & 0 & 0 & $=$ & 0 & 0 & & 0 & 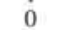 & 0 & 0 & & 0 & & 0 & 0 & 0 \\
\hline $4 \mathrm{H}-1,8$ & 22.52 & 0.0625 & 12.6838 & 0.05 & 132 & 308 & 189 & 8 & 6 & 33 & 6 & 39 & 0 & 0 & 0 & 0 & 0 & 5 & 1 & 0 & 12 & 0 & 8 & 0 & & 0 & 0 & 0 \\
\hline $4 \mathrm{H}-2$ & 24.01 & 0. & 16 & & 54 & 7 & 5 & 18 & 70 & 44 & 4 & 6 & 2 & 0 & 0 & 0 & 0 & 3 & 0 & 0 & & 0 & 2 & 0 & 0 & 0 & 0 & 0 \\
\hline $\begin{array}{l}4 \pi-2, \\
4 \mathrm{H}-3,\end{array}$ & 25.92 & 0.0313 & 14 & & 16 & 70 & 492 & $\begin{array}{r}10 \\
5\end{array}$ & 43 & 51 & 2 & 55 & 11 & 0 & 0 & 0 & 0 & 4 & 0 & 0 & 34 & 0 & 11 & 0 & 0 & 0 & 0 & 0 \\
\hline $4 \mathrm{H}-4,88-90$ & 27.08 & 0.0313 & 17.8245 & 0.1579 & 4 & 16 & 10 & 1 & 0 & 3 & 0 & 2 & 0 & 0 & 0 & 0 & 0 & 0 & 0 & 0 & 0 & 0 & . & 0 & 0 & 0 & 0 & 0 \\
\hline $4 \mathrm{H}-5,96-98$ & 28.66 & 0.0156 & 12.8155 & 0.4296 & 23 & 789 & 606 & 20 & 46 & 56 & 6 & 21 & 1 & 0 & 0 & 0 & 0 & 5 & 2 & 0 & 25 & 0 & 0 & 1 & 0 & 0 & 0 & 0 \\
\hline $4 \mathrm{H}-6,108-110$ & 30.23 & 0.0156 & 15.5024 & 2.0099 & 35 & 369 & 302 & 3 & 11 & 15 & 6 & 9 & 2 & 0 & 0 & 0 & 0 & 1 & 2 & 1 & 17 & 0 & & 0 & 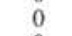 & 0 & 0 & 0 \\
\hline $4 \mathrm{H}-7,62-64$ & 31.32 & 0.1250 & 16.5603 & 0.0750 & 33 & 923 & 621 & 6 & 19 & 91 & 5 & 73 & 13 & 0 & 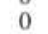 & 0 & 0 & 4 & 5 & 0 & 84 & 0 & & 0 & & 0 & 6 & 0 \\
\hline $5 \mathrm{H}-1,19-21$ & 31.39 & 0.0078 & 14.8123 & 0. & 10 & 462 & 75 & 0 & 34 & 153 & 11 & 100 & & 0 & 0 & 0 & O & 60 & 10 & 0 & $\begin{array}{l}14 \\
14\end{array}$ & 0 & & 0 & & 0 & 0 & 0 \\
\hline & 31.64 & & 18 & & 506 & 30 & 119 & 0 & & 48 & & 44 & 8 & 0 & & 0 & & & 2 & 0 & & & & 0 & & 0 & & 0 \\
\hline $5 !$ & 3 & 0. & $\begin{array}{l}18.02 \\
14.02\end{array}$ & 1. & 172 & 22 & . & 0 & 0 & 2 & 0 & 4 & 2 & $\begin{array}{l}0 \\
0\end{array}$ & & 0 & 0 & 1 & 0 & c & & & 0 & 0 & & 0 & 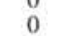 & 0 \\
\hline & & & 14 & 0.44 & 8 & & 20 & 1 & 2 & 65 & 4 & 8 & 6 & 0 & & 0 & 0 & 26 & 1 & 0 & & 0 & 0 & 0 & & 0 & 0 & 0 \\
\hline $5 \mathrm{H}-5,133-135$ & 37.41 & 0.0626 & 16.8116 & 0.3300 & $285^{\circ}$ & 454 & 242 & 3 & $\begin{array}{r}24 \\
0\end{array}$ & 51 & 0 & 70 & 14 & 0 & 0 & 0 & 0 & 20 & 0 & 0 & 66 & 0 & 2 & 0 & 0 & 0 & 0 & 0 \\
\hline $5 \mathrm{H}-6,90-92$ & 38.48 & 1.0000 & 18.0135 & 0.118 & 0 & 0 & 0 & 0 & 0 & H. & 0 & 0 & 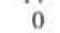 & 0 & - & 0 & 0 & 0 & 0 & 0 & 0 & 0 & 0 & 0 & 0 & 0 & 0 & 0 \\
\hline $5 \mathrm{H}-7,88-9$ & 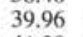 & 0.0352 & 18.01 & & 415 & 301 & 205 & 0 & 0 & 22 & 0 & 26 & 5 & 0 & 0 & 0 & 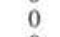 & 2 & 0 & 0 & 41 & 0 & 0 & 0 & & 0 & 0 & 0 \\
\hline 61 & & 0. & & & 370 & 320 & 181 & 2 & 1 & 21 & 2 & 50 & 7 & 0 & 0 & 0 & 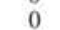 & 4 & 5 & 0 & 45 & 0 & & 0 & & 0 & 0 & 0 \\
\hline 25 & & 0. & & & 83 & 2 & 24 & 0 & 0 & 2. & 0 & 0 & 0 & 0 & 0 & 0 & 0 & 1 & 3 & 0 & 4. & 0 & 0 & 0 & & 0 & 0 & 0 \\
\hline $6 \mathrm{H}-3$, & 44.97 & 0. & & & 2 & 42 & 30 & 0 & 6 & 2 & 4 & 48 & 4 & 0 & & 0 & & & 2 & & & & & 0 & & 0 & 0 & 0 \\
\hline 61 & $48-2$ & 0 & 16 & 0. & 277 & & & 1 & 3 & 1 & $i$ & & 2 & 0 & & ( & & & 0 & & & & & 0 & & 0 & & 0 \\
\hline 61 & 4 & & & 0.20 & 2 & & & 0 & 2 & 1 & 0 & $\begin{array}{l}10 \\
19\end{array}$ & 1 & 0 & & 0 & 0 & 3 & 0 & 0 & & & c & 0 & & 0 & 0 & 0 \\
\hline & 5 & 0 & is & 0. & 281 & 45 & 22 & 0 & 1 & 44 & 0 & 8 & 4 & 0 & & 0 & 0 & 7 & 0 & 0 & 94 & 0 & & 0 & & 0 & 0 & 0 \\
\hline & & & 11.0872 & 0 . & 52 & 364 & 252 & 0 & 15 & 14 & 4 & $\begin{array}{l}54 \\
57\end{array}$ & 4 & 0 & & 0 & 0 & 11 & 0 & & 3 & 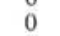 & 0 & 0 & & 0 & 0 & 0 \\
\hline & & & & & 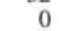 & 0 & 0 & 0 & 0 & 0 & 0 & 0 & & 0 & 0 & 0 & 0 & 0 & 0 & 0 & 0 & 0 & c & 0 & & 0 & 0 & 0 \\
\hline & & & & & 0 & 0 & 0 & 0 & 0 & 0 & 0 & 0 & & 0 & 0 & 0 & 0 & &  & 0 & 0 & 0 & & 0 & & 0 & 0 & 0 \\
\hline 71 & & & 17.2 & & & 0 & & 0 & 0 & 0 & 0 & 0 & 0 & 0 & & ( & & & 0 & 0 & 0 & 0 & & 0 & & 0 & 0 & 0 \\
\hline 71 & & 1. & 18 & 3. & & 0 & 0 & 0 & 0 & 0 & 0 & 0 & 0 & 0 & & ( & & & 0 & & 0 & & & 0 & & 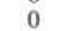 & 0 & 0 \\
\hline & & 1.00 & 12 & 0. & 0 & 0 & 0 & 0 & 0 & 0 & 0 & 0 & 0 & 0 & & ( & 0 & & 0 & & 0 & & & 0 & & 0 & 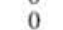 & 0 \\
\hline & & & is & & 0 & 0 & 0 & 0 & 0 & 0 & 0 & 0 & 0 & 0 & & 0 & 0 & & 0 & & 0 & & & 0 & & 0 & 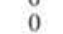 & 0 \\
\hline & & & & & 0 & 0 & 0 & 0 & 0 & 0 & 0 & 0 & 0 & (c & & 0 & & & & & & & & 0 & & 0 & 0 & 0 \\
\hline & & & & & 0 & 0 & 0 & 0 & 0 & 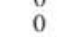 & 0 & 0 & & 0 & c & ( & c & & 0 & & 0 & 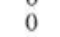 & & 0 & & 0 & & 0 \\
\hline & & & & & 0 & 0 & 0 & 0 & 0 & 0 & & 0 & & 0 & 0 & c & 0 & & 0 & 0 & 0 & 0 & & 0 & & 0 & 0 & 0 \\
\hline 81 & & i. & & & 0 & 0 & 0 & 0 & 0 & 0 & & 0 & 0 & 0 & 0 & 0 & 0 & & 0 & 0 & 0 & 0 & & 0 & 0 & 0 & 0 & 0 \\
\hline $8-101$ & 6 & 1.00 & 31.0085 & 0.8 & 0 & 0 & 0 & 0 & 0 & 0 & 0 & 0 & 0 & 0 & 0 & 0 & 0 & & 0 & 0 & 0 & 0 & & 0 & 0 & 0 & 0 & 0 \\
\hline 0 & 4 & 1.00 & 24.6532 & 0.43 & 0 & 0 & 0 & 0 & 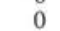 & 0 & 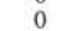 & 0 & 0 & 0 & 0 & 0 & 0 & & 0 & 0 & 0 & 0 & & 0 & 0 & 0 & 0 & 0 \\
\hline $9 \mathrm{l}$ & 7 & 1.0 & 17.17 & 0. & 0 & 0 & 0 & 0 & & 0 & & 8 & 0 & 0 & 0 & & 0 & & 0 & 0 & 0 & 0 & & 0 & 0 & 0 & 0 & 0 \\
\hline 91 & 7 & i. & 17 & 0.27 & 0 & 0 & 0 & $\begin{array}{l}0 \\
0\end{array}$ & 0 & 1 & & 0 & & 0 & 0 & & 0 & & 0 & 0 & 0 & $\begin{array}{l}0 \\
0\end{array}$ & & 0 & 0 & & 0 & 0 \\
\hline & & 1.00 & 1690 & & & 07 & 34 & 0 & 21 & 14 & 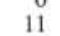 & 18 & & 0 & 0 & 0 & 0 & & 0 & 0 & 4 & 0 & & 0 & 0 & & 0 & 0 \\
\hline $2 X-1,33-35$ & 96.03 & 1.0000 & & & & 0 & & 0 & 0 & 0 & 0 & 0 & & 0 & & & 0 & & 0 & & 0 & & & 0 & & 0 & 0 & 0 \\
\hline $\mathrm{X}-2,32-34$ & 97.52 & 1.0000 & $\begin{array}{l}16.74083 \\
16.7443\end{array}$ & $\begin{array}{l}0.6525 \\
1.7101\end{array}$ & & 0 & 0 & 0 & 0 & 0 & 0 & 0 & 0 & 0 & 0 & 0 & 0 & & 0 & 0 & 年 & 0 & 0 & 0 & 0 & 0 & 0 & ( \\
\hline
\end{tabular}


$\begin{array}{lllllllllllllllllll}\begin{array}{l}\text { Core, section, } \\ \text { interval }(\mathrm{cm})\end{array} & \begin{array}{c}\text { Depth } \\ \text { (mbsf) }\end{array} & \text { Split } & \text { SedWt } & \text { SandWt } & \text { Ben } & \text { Pla } & \text { Pdl } & \text { Pdr Bul Qui Glu Cfu Uvu Uni lot Par Juv Ind Sci Gra Min The Fal Inf Hum Rub Hir Rube }\end{array}$

139-857 A-

$\begin{array}{lll}39-857 \mathrm{~A}- & & \\ 1 \mathrm{H}-1,0-1 & 1.90 & 0.0078 \\ 1 \mathrm{H}-1,79-81 & 2.69 & 0.0313\end{array}$

$\begin{array}{lllll}\mathrm{H}-2,125-129 & 2.69 & 0.0313 & 12.5607 & 0.2305 \\ 4.65 & 0.0313 & 13.8467 & 0.1399\end{array}$

$\begin{array}{llllll}1 \mathrm{H}-3,10-13 & 5.00 & 0.0078 & 12.6154 & 0.2284\end{array}$

$\begin{array}{llllll}\text { IH-5, 89-91 } & 8.79 & 0.0078 & 9.5719 & 0.1230\end{array}$

$\begin{array}{llllll}2 \mathrm{H}-\mathrm{I}, 45-48 & 11.85 & 0.0039 & & \\ & & & \end{array}$

$2 \mathrm{H}-1,97-99$

$\begin{array}{llll}12.37 & 0.0078 & 17.3152 & 0.2049\end{array}$

$\begin{array}{lll}2 \mathrm{H}-1,105-107 & 12.45 & 0.0313 \\ 2 \mathrm{H}-2,20-22 & 13.10 & 0.0039\end{array}$

$\begin{array}{llllll}2 \mathrm{H}-2,96-98 & 13.86 & 0.0078 & 16.8847 & 0.2345\end{array}$

$\begin{array}{lllll}2 \mathrm{H}-2,129-131 & 14.19 & 0.0156 & 20.5320 & 0.0296\end{array}$

\begin{tabular}{lll}
$2 \mathrm{H}-3,98-100$ & 15.38 & 0.0625 \\
\hline
\end{tabular}

$24.12-131 \quad 15.02 \quad 0.00625$



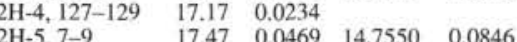

$2 \mathrm{H}-5,7-9$

$\begin{array}{llll}17.47 & 0.0469 & 14.7550 & 0.0846 \\ 17.62 & 0.0078 & & \end{array}$

$2 \mathrm{H}-6,9-11 \quad 18.99 \quad 0.0156$

$\begin{array}{lllll}2 \mathrm{H}-7,26-28 & 20.66 & 0.0313 & 15.4581 & 0.0656\end{array}$

$\begin{array}{llllll}4 \mathrm{H}-1,124-126 & 23.14 & 1.0000 & 22.9955 & 0.3397\end{array}$

$\begin{array}{llllllll}4 \mathrm{H}-3.34 & 66 & 25.54 & 0.7500 & 17.3573 & 0.0327\end{array}$

$\begin{array}{lllll}4 \mathrm{H}-3,100-103 & 25.90 & 1.0000 & 24.8423 & 0.8424\end{array}$

$\begin{array}{lllll}4 \mathrm{H}-3,125-127 & 26.15 & 0.0938 & 14.2653 & 0.0799 \\ 4 \mathrm{H}-4,12-14 & 26.52 & 0.3750 & 12.5367 & 0.0926\end{array}$

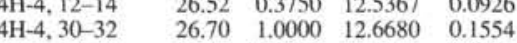

$\begin{array}{llllll}4 \mathrm{H}-4,38-40 & 26.78 & 0.0625 & 12.7722 & 0.0827\end{array}$

$4 \mathrm{H}-4,49-5 \mathrm{I}$

$\begin{array}{llll}26.89 & 0.0781 & & \\ 27.10 & 1.0000 & 16.7080 & 0.0187\end{array}$

$\begin{array}{llllll} & 28.30 & 0.0781 & 17.2686 & 0.0385\end{array}$

$\begin{array}{llllll}4 \mathrm{H}-5,127-129 & 29.17 & 0.0313 & & \\ 4 \mathrm{H}-7,43-47 & 31.33 & 0.0313 & 17.7345 & 0.0696\end{array}$

$\begin{array}{lllll}5 \mathrm{H}-2,13-17 & 33.03 & 0.5000 & 22.6066 & 0.0195\end{array}$

$\begin{array}{llllll}5 \mathrm{H}-2,38-42 & 33.28 & 1.0000 & 29.2689 & 0.6903\end{array}$

$\begin{array}{lllll}5 \mathrm{H}-3,48-52 & 34.88 & 1.0000 & 25.5451 & 0.1559\end{array}$

$5 \mathrm{H}-4,9-13$

$\begin{array}{llllll}5 H-4,57-61 & 36.47 & 0.0625 & 19.5133 & 0.5970\end{array}$

$\begin{array}{lllll}5 \mathrm{H}-4,70-72 & 36.60 & 0.4375 & 13.2702 & 0.0555 \\ 5 \mathrm{H}-4,130-132 & 37.20 & 0.1250 & 12.6538 & 0.1188\end{array}$

$\begin{array}{rrrrrr}5 \mathrm{H}-5,105-107 & 38.45 & 0.1250 & 8.2780 & 0.0374\end{array}$

\begin{tabular}{lllll}
$5 \mathrm{H}-5,126-130$ & 38.66 & 1.0000 & 16.2646 & 0.3497 \\
\hline
\end{tabular}

$\begin{array}{llllll}5 \mathrm{H}-5,140-142 & 38.80 & 0.0313 & 14.7918 & 0.1055 \\ 5 \mathrm{H}-6,126-130 & 40.16 & 1.0000 & 25.7329 & 0.6689\end{array}$

$\begin{array}{lllll}5 \mathrm{H}-6,126-130 & 40.16 & 1.0000 & 25.7329 & 0.6689 \\ 5 \mathrm{H}-7.18-22 & 40.58 & 1.0000 & 22.3659 & 0.3944\end{array}$

$\begin{array}{llllll}5 \mathrm{H}-7,18-22 & 40.58 & 1.0000 & 22.3659 & .3944 \\ 6 \mathrm{H}-1,59-63 & 41.49 & 0.0078 & 21.1804 & 0.2023\end{array}$

$\begin{array}{llllll}6 \mathrm{H}-2,76-80 & 43.16 & 0.0195 & 23.0630 & 0.2720\end{array}$

$\begin{array}{lll}6 \mathrm{H}-3,27-31 & 44.17 & 0.0059\end{array}$

$6 \mathrm{H}-4,66-70 \quad 46.06 \quad 0.0078$

$6 \mathrm{H}-5,4-8 \quad 46.94 \quad 0.1250$

\begin{tabular}{lll}
$6 \mathrm{H}-5,45-49$ & 47.35 & 1.0000 \\
\hline & 50.28 & 0.0313
\end{tabular}

$\begin{array}{lllll}7 \mathrm{H}-3,37-39 & 52.59 & 0.0156 & 24.6610 & 0.1054\end{array}$

$7 \mathrm{H}-4,1-5$

7H-4, 85-89

$53.63 \quad 0.0078$

\begin{tabular}{lllll}
5 & 54.47 & 0.0020 & 26.7248 & 0.5848 \\
\hline & 55.52 & 0.0098 & 27.5015 & 0.198
\end{tabular}

$\begin{array}{llllll}7 \mathrm{H}-6,121-125 & 56.89 & 0.0156 & 26.2915 & 0.0795 \\ 7 \mathrm{H} & 128-125 & 57.35 & 1.0000 & 27.4537 & 0.0088\end{array}$

$\begin{array}{lllll}8 \mathrm{H}-1,119-123 & 61.09 & 0.0098 & 18.9148 & 0.7795 \\ 8 \mathrm{H}-2,21-25 & 61.61 & 0.0156 & 23.4379 & 0.1262\end{array}$
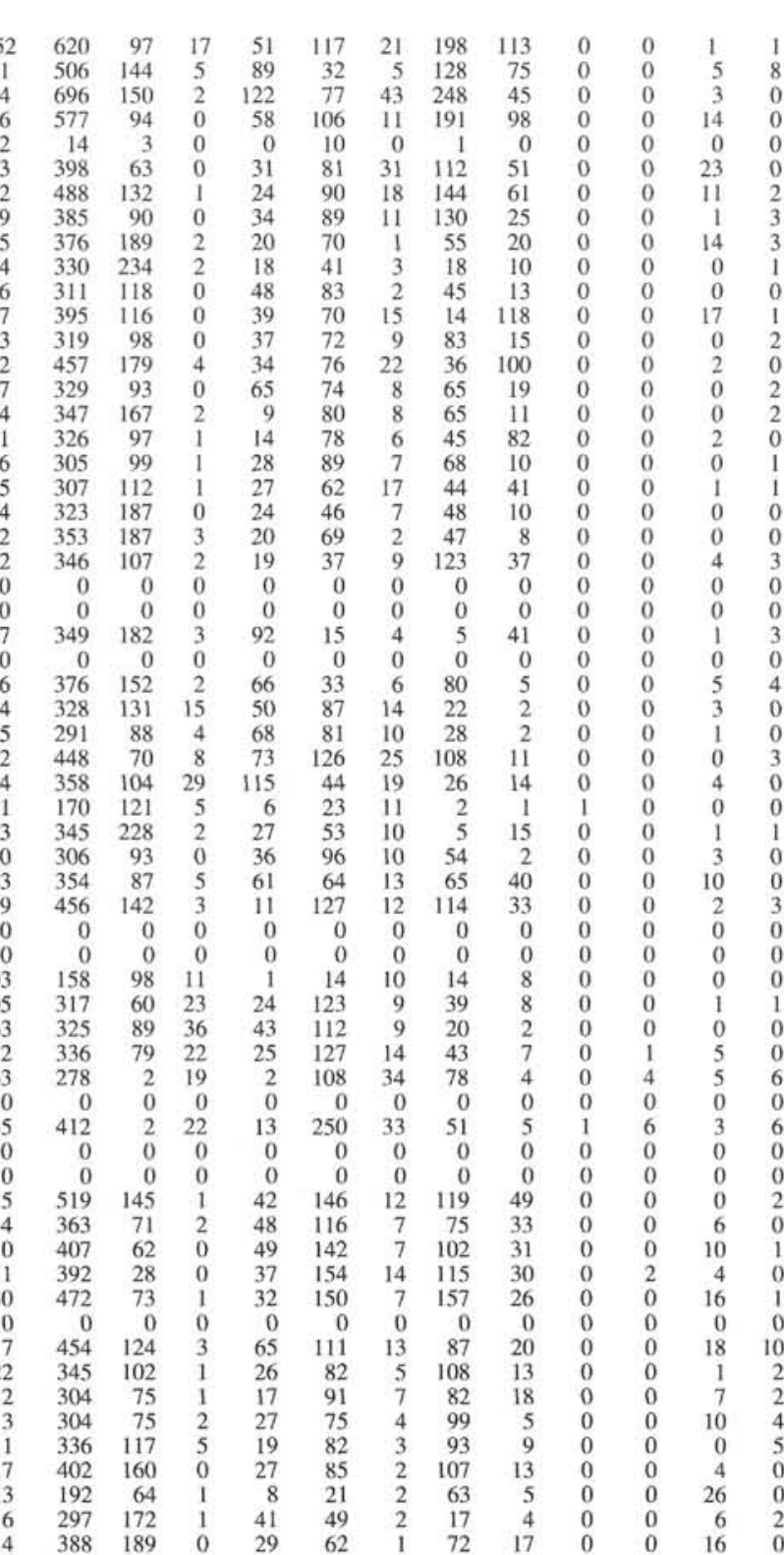

\begin{tabular}{|c|c|c|c|c|c|c|c|c|c|c|}
\hline 1 & 3 & 0 & 0 & 0 & 0 & 0 & 0 & 0 & 0 & 0 \\
\hline 10 & 1 & 4 & 0 & 0 & 0 & 0 & 0 & 0 & 0 & 0 \\
\hline 2 & 2 & 0 & 2 & 0 & 0 & 0 & 0 & 0 & 0 & 0 \\
\hline 4 & 1 & 0 & 0 & 0 & 0 & 0 & 0 & 0 & 0 & 0 \\
\hline 0 & 0 & 0 & 0 & 0 & 0 & 0 & 0 & 0 & 0 & 0 \\
\hline 2 & 4 & 0 & 0 & 0 & 0 & 0 & 0 & 0 & 0 & 0 \\
\hline 1 & 4 & 0 & 0 & 0 & 0 & 0 & 0 & 0 & 0 & 0 \\
\hline 2 & 0 & 0 & 0 & 0 & 0 & 0 & 0 & 0 & 0 & 0 \\
\hline$i$ & 0 & 0 & 1 & 0 & 0 & 0 & 0 & 0 & 0 & 0 \\
\hline 2 & 0 & i & 0 & 0 & 0 & 0 & 0 & 0 & 0 & 0 \\
\hline 2 & 0 & 0 & 0 & 0 & 0 & 0 & 0 & 0 & 0 & 0 \\
\hline 1 & 2 & 0 & 1 & $\begin{array}{l}0 \\
1\end{array}$ & 0 & 0 & 0 & 0 & $\begin{array}{l}0 \\
0\end{array}$ & 0 \\
\hline 2 & 0 & 0 & 0 & 0 & 0 & 0 & 1 & 0 & 0 & 0 \\
\hline 4 & 0 & 0 & 0 & 0 & 0 & 0 & 0 & 0 & 0 & 0 \\
\hline 1 & 2 & 0 & 0 & 0 & 0 & 0 & 0 & 0 & 0 & 0 \\
\hline i & 1 & 0 & 0 & 0 & 0 & 0 & 1 & 0 & 0 & 0 \\
\hline 1 & 0 & 0 & 0 & 0 & 0 & 0 & 0 & 0 & 0 & 0 \\
\hline i & 1 & 0 & 0 & 0 & 0 & 0 & 0 & 0 & 0 & 0 \\
\hline i & 0 & 0 & 0 & 0 & 0 & 0 & 0 & 0 & 0 & 0 \\
\hline 1 & 0 & 0 & 0 & 0 & 0 & 0 & 0 & 0 & $\begin{array}{l}0 \\
0\end{array}$ & 0 \\
\hline 4 & 3 & 0 & 9 & $\begin{array}{l}0 \\
0\end{array}$ & 0 & 0 & 1 & 0 & 0 & 0 \\
\hline 3 & 1 & 1 & 0 & 0 & 0 & 0 & 0 & 0 & 0 & 0 \\
\hline 0 & 0 & 0 & 0 & 0 & 0 & 0 & 0 & 0 & 0 & 0 \\
\hline 0 & 0 & 0 & 0 & 0 & 0 & 0 & 0 & 0 & 0 & 0 \\
\hline 0 & 2 & 0 & 0 & 0 & 0 & 0 & 0 & 0 & 0 & 0 \\
\hline 0 & 0 & 0 & 0 & 0 & 0 & 0 & 0 & 0 & 0 & 0 \\
\hline 9 & 0 & 0 & 7 & 0 & 0 & 3 & 0 & 4 & 0 & 0 \\
\hline 2 & 0 & 0 & $i$ & 0 & 0 & 0 & 0 & 1 & 0 & 0 \\
\hline 3 & $\begin{array}{l}0 \\
0\end{array}$ & 0 & 5 & 0 & 0 & 0 & 0 & 1 & 0 & 0 \\
\hline 4 & 1 & 0 & 14 & 0 & 4 & 0 & 0 & 1 & 0 & 0 \\
\hline 1 & $i$ & 1 & 0 & 0 & 0 & 0 & 0 & 0 & 0 & 0 \\
\hline 0 & 0 & 0 & 0 & 0 & 0 & 0 & 0 & 0 & 0 & 0 \\
\hline 2 & 1 & 0 & 0 & 0 & 0 & 0 & 0 & 0 & 0 & 0 \\
\hline 8 & 1 & 0 & 3 & 0 & 0 & 0 & 0 & 0 & 0 & 0 \\
\hline 3 & 2 & 0 & 0 & 0 & 2 & 0 & 0 & 0 & 0 & 0 \\
\hline 8 & 0 & 1 & 0 & 0 & 0 & 0 & 0 & 0 & 0 & 0 \\
\hline $\begin{array}{l}\circ \\
0\end{array}$ & 0 & 0 & 0 & 0 & 0 & 0 & 0 & 0 & 0 & 0 \\
\hline 0 & 0 & 0 & 0 & 0 & 0 & 0 & 0 & 0 & 0 & 0 \\
\hline 1 & 1 & 0 & 0 & 0 & 0 & 0 & 0 & 0 & 0 & 0 \\
\hline 3 & 3 & 0 & 0 & 0 & 0 & 22 & 0 & 0 & 0 & 0 \\
\hline 2 & 3 & 0 & 8 & 0 & 0 & 1 & 0 & 0 & 0 & 0 \\
\hline 6 & 4 & 0 & 2 & 0 & 0 & 0 & 1 & 0 & 0 & 0 \\
\hline 4 & 2 & 1 & 3 & 0 & 0 & 0 & 1 & 2 & 3 & 0 \\
\hline 0 & 0 & 0 & 0 & 0 & 0 & 0 & 0 & 0 & 0 & 0 \\
\hline 12 & 0 & 1 & 1 & 0 & 0 & 1 & 1 & 3 & 1 & 0 \\
\hline $\begin{array}{r}12 \\
0\end{array}$ & 0 & $\begin{array}{l}1 \\
0\end{array}$ & 0 & $\begin{array}{l}0 \\
0\end{array}$ & 0 & 0 & 0 & 0 & 0 & 0 \\
\hline 0 & 0 & 0 & 0 & 0 & 0 & 0 & 0 & 0 & 0 & 0 \\
\hline 0 & 2 & 0 & 1 & 0 & 0 & 0 & 0 & 0 & 0 & 0 \\
\hline 3 & 1 & 0 & 1 & 0 & 0 & 0 & 0 & 0 & 0 & 0 \\
\hline 2 & 0 & 1 & 0 & 0 & 0 & 0 & 0 & 0 & 0 & 0 \\
\hline 8 & 0 & 0 & 0 & 0 & 0 & 0 & 0 & 0 & 0 & 0 \\
\hline 8 & 1 & 0 & 0 & 0 & 0 & 0 & 0 & 0 & 0 & 0 \\
\hline 0 & 0 & 0 & 0 & 0 & 0 & 0 & 0 & 0 & 0 & 0 \\
\hline 2 & 1 & 0 & 0 & 0 & 0 & 0 & 0 & 0 & 0 & 0 \\
\hline 3 & 2 & 0 & 0 & 0 & 0 & 0 & 0 & 0 & 0 & 0 \\
\hline 2 & 1 & 1 & 0 & 0 & 0 & 0 & 0 & 0 & 0 & 0 \\
\hline 2 & $i$ & 0 & 0 & 0 & 0 & 0 & 0 & 0 & 0 & 0 \\
\hline 2 & i & 0 & 0 & 0 & 0 & 0 & 0 & 0 & 0 & 0 \\
\hline 1 & 2 & 0 & 1 & 0 & 0 & 0 & 0 & 0 & 0 & 0 \\
\hline 2 & 0 & 0 & 0 & 0 & 0 & 0 & 0 & 0 & 0 & 0 \\
\hline 2 & 1 & 0 & 0 & 0 & 0 & 0 & 0 & 0 & 0 & 0 \\
\hline 0 & 0 & 0 & 2 & 0 & 0 & 0 & 0 & 0 & 0 & 0 \\
\hline
\end{tabular}




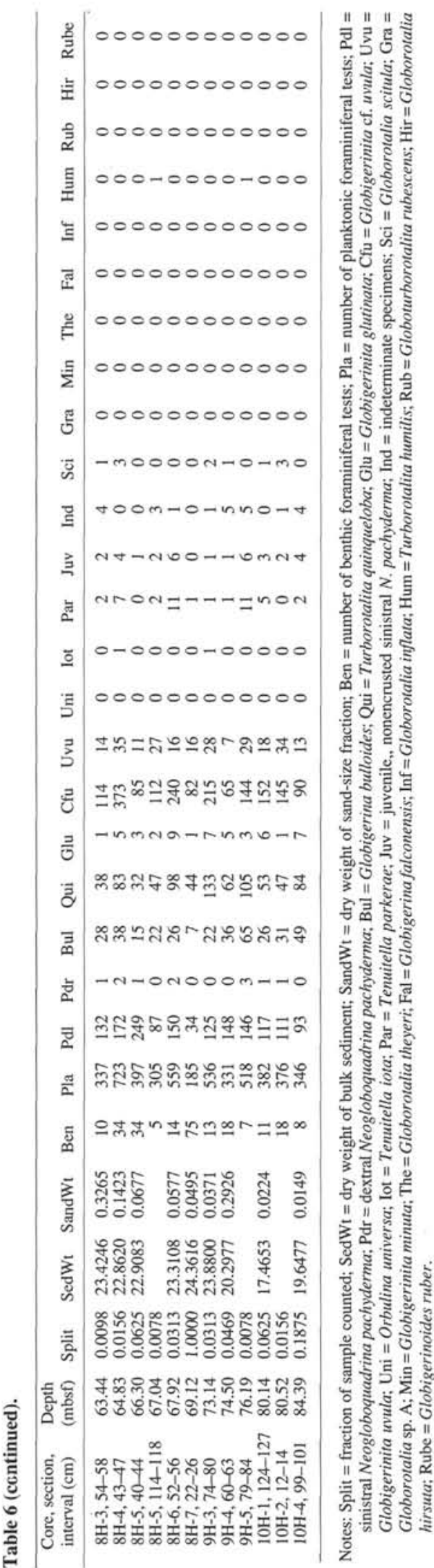

ward to a position just south of the Leg 139 sites at $48^{\circ} 30^{\prime} \mathrm{N}$ latitude during the penultimate interglacial period. The sites constrain maximum northward migration of the subarctic boundary, but do not delimit the northern extent of transitional waters.

\section{TAXONOMIC NOTES}

Globigerina bulloides d'Orbigny Globigerina bulloides d'Orbigny, 1826, ser. 1, v. 7, p. 277 , nos. 17 and 76.

Globigerina clarkei Rögl and Bolli Globigerina clarkei Rögl and Bolli, 1973, p. 563, pl. 4, figs. 13-15. Note: This species was included in the Tr. quinqueloba counting group because it is difficult to distinguish from poorly preserved forms of the latter.

Globigerina falconensis Blow Globigerina falconensis Blow, 1959, p. 177, pl. 9, figs. 40a-c, 41.

Globigerinita glutinata (Egger) Globigerina glutinata Egger, 1893, p. 371, pl. 13, figs. 19-21.

Globigerinita minuta (Natland) Globigerinoides minuta Natland, 1938, p. 150, pl. 7, figs. 2-3. Note: Most Gt. minuta at Leg 139 sites do not have a bulla. The ampulate form of Gt. minuta (Natland) as illustrated in fig. $2.7 \mathrm{k}$ of Hemleben et al. (1989) is rare in Leg 139 samples. The form is gradational with Gt. uvula and was grouped with the Gt. uvula counting group during the census.

Globigerinita uvula (Ehrenberg)

Pylodexia uvula Ehrenberg, 1861, p. 206, 207, 308.

Note: The group includes a low spired form intermediate between Gt. uvula and Gt. minuta referred to Gt. cf. uvula. All three taxa are included in the Gt. uvula counting group tabulated in the census.

Globigerinoides ruber (d'Orbigny) Globigerina ruber d'Orbigny, 1839a, p. 82; v. 8, pl. 4, figs. 12-14.

Globorotalia hirsuta (d'Orbigny) Rotalina hirsuta d'Orbigny, 1839b, p. 131, pl.1, figs. 34-36.

Globorotalia inflata (d'Orbigny) Globigerina inflata d'Orbigny, 1839b, p. 134, pl. 12, figs 7-9.

Globorotalia scitula (Brady) Pulvinulina scitula Brady, 1882, p. 716; figured in Brady, 1884, pl. 103 , figs. $7 \mathrm{a}-\mathrm{c}$.

Globorotalia theyeri Fleisher Globorotalia theyeri Fleisher, 1974, p. 1028, pl. 12, fig. 9; pl. 13, figs. $1-5$.

Globoturborotalita rubescens (Hofker) Globigerina rubescens Hofker, 1956, v. 15, p. 234, pl. 32, fig. 26, pl. 35 , figs. $18-21$.

Neogloboquadrina pachyderma (Ehrenberg) Aristospira pachyderma Ehrenberg, 1861, p. 276, 277, and 303. Note: Most sinistral coiling forms are the encrusted Group A variety of Reynolds and Thunell (1986) and Form 1 of Keller (1978), and most dextral coiling forms are the reticulate and lobate Group B variety of Reynolds and Thunell (1986) and Forms 2 and 3 of Keller (1978),

Orbulina universa d'Orbigny Orbulina universa d'Orbigny, 1839a, p. 3, pl. 1, fig. 1 .

Tenuitella iota (Parker) Globigerinita iota Parker, 1962, p. 250-252, pl. 10, figs. 26-30.

Tenuitella parkerae (Brönnimann and Resig) Globorotalia parkerae Brönnimann and Resig, 1971, p. 1280-1281, pl. 43 , figs. 7,10 ; pl. 47 , figs. 4,6 ; pl. 48 , figs. $2-3$.

Turborotalita humilis (Brady) Truncatulina humilis Brady, 1884, p. 665, pl. 94, fig. 7.

Turborotalita quinqueloba (Natland) Globigerina quinqueloba Natland, 1938, p. 149, pl. 6, fig. 7. Note: The Ga. quinqueloba group consists of Ga. quinqueloba Natland and $G a$. clarkei (Rögl and Bolli), two taxa that are difficult to distinguish as discussed in Hemleben et al. (1989), p. 13.

\section{ACKNOWLEDGMENTS}

I heartily thank R. Timothy Patterson and an anonymous reviewer for their helpful comments that improved this manuscript. I especially want to acknowledge and thank my colleagues on board Leg 139 for the open exchange of ideas and data which provided the context for this 
Table 7. Species composition (relative frequency \%) of clusters.

\begin{tabular}{|c|c|c|c|c|c|c|c|}
\hline Sample & Pdl & Pdr & Bul & Qui & Glu & Uvu & Tran \\
\hline \multicolumn{8}{|l|}{ Cluster la } \\
\hline $856 \mathrm{~A}-6 \mathrm{H}-6,46-48$ & 73 & 0 & 1 & 4 & 0 & 18 & 0 \\
\hline $856 \mathrm{~A}-6 \mathrm{H}-6,112-114$ & 74 & 0 & 1 & 5 & 0 & 18 & 0 \\
\hline $856 \mathrm{~A}-6 \mathrm{H}-3,127-129$ & 72 & 0 & 1 & 5 & 1 & 18 & 0 \\
\hline $856 \mathrm{~A}-7 \mathrm{H}-2,12-14$ & 69 & 0 & 4 & 4 & 1 & 19 & 0 \\
\hline $856 \mathrm{~A}-4 \mathrm{H}-7,62-64$ & 67 & 1 & 2 & 10 & 1 & 18 & 0 \\
\hline $856 \mathrm{~A}-5 \mathrm{H}-7,88-90$ & 68 & 0 & 0 & 7 & 0 & 24 & 0 \\
\hline $857 \mathrm{~A}-8 \mathrm{H}-5,40-44$ & 63 & 0 & 4 & 8 & 1 & 24 & 0 \\
\hline $856 \mathrm{~A}-4 \mathrm{H}-2,81-83$ & 67 & 2 & 9 & 6 & 1 & 15 & 0 \\
\hline $856 \mathrm{~A}-4 \mathrm{H}-3,122-124$ & 69 & 1 & 6 & 7 & 0 & 14 & 2 \\
\hline $856 \mathrm{~A}-4 \mathrm{H}-4,88-90$ & 63 & 6 & 0 & 19 & 0 & 13 & 0 \\
\hline $856 \mathrm{~A}-2 \mathrm{H}-6,86-88$ & 59 & 1 & 10 & 8 & 3 & 17 & 0 \\
\hline $857 \mathrm{~A}-2 \mathrm{H}-5,22-24$ & 58 & 0 & 7 & 14 & 2 & 18 & 0 \\
\hline $856 \mathrm{~A}-4 \mathrm{H}-1,82-84$ & 61 & 3 & 2 & 11 & 2 & 17 & 3 \\
\hline $857 \mathrm{~A}-5 \mathrm{H}-4,9-13$ & 62 & 7 & 1 & 9 & 6 & 14 & 0 \\
\hline $857 \mathrm{~A}-2 \mathrm{H}-1,105-107$ & 71 & 1 & 5 & 12 & 1 & 8 & 0 \\
\hline $857 \mathrm{~A}-4 \mathrm{H}-5,40-44$ & 66 & 1 & 8 & 15 & 3 & 6 & 0 \\
\hline $857 \mathrm{~A}-4 \mathrm{H}-4,70-74$ & 71 & 3 & 4 & 14 & 6 & 2 & 1 \\
\hline $857 \mathrm{~A}-8 \mathrm{H}-1,119-123$ & 58 & 0 & 14 & 16 & 1 & 7 & 0 \\
\hline $856 \mathrm{~A}-4 \mathrm{H}-6,108-110$ & 82 & 1 & 3 & 4 & 2 & 8 & 0 \\
\hline $856 \mathrm{~A}-6 \mathrm{H}-2,123-125$ & 86 & 0 & 0 & 4 & 0 & 7 & 0 \\
\hline $856 \mathrm{~A}-4 \mathrm{H}-5,96-98$ & 77 & 3 & 6 & 7 & 1 & 6 & 0 \\
\hline \multicolumn{8}{|l|}{ Cluster $1 \mathrm{~b}$} \\
\hline $856 \mathrm{~A}-5 \mathrm{H}-3,135-137$ & 61 & 0 & 0 & 9 & 0 & 30 & 0 \\
\hline $856 \mathrm{~A}-6 \mathrm{H}-1,68-70$ & 57 & 1 & 0 & 7 & 1 & 32 & 1 \\
\hline $856 \mathrm{~A}-5 \mathrm{H}-5,133-135$ & 53 & 1 & 0 & 11 & 0 & 33 & 0 \\
\hline $856 \mathrm{~A}-7 \mathrm{H}-1,48-50$ & 48 & 0 & 0 & 10 & 0 & 40 & 0 \\
\hline $857 \mathrm{~A}-2 \mathrm{H}-1,97-99$ & 50 & 1 & 5 & 19 & 0 & 20 & 0 \\
\hline $857 \mathrm{~A}-2 \mathrm{H}-6,9-11$ & 53 & 1 & 6 & 20 & 1 & 18 & 0 \\
\hline $857 \mathrm{~A}-2 \mathrm{H}-4,12-14$ & 48 & 1 & 3 & 23 & 2 & 22 & 0 \\
\hline $856 \mathrm{~A}-5 \mathrm{H}-4,88-90$ & 47 & 0 & 6 & 15 & 1 & 25 & 0 \\
\hline $857 \mathrm{~A}-8 \mathrm{H}-2,21-25$ & 49 & 0 & 7 & 16 & 0 & 23 & 0 \\
\hline $857 \mathrm{~A}-9 \mathrm{H}-4,60-63$ & 45 & 0 & 11 & 19 & 2 & 22 & 0 \\
\hline $856 \mathrm{~A}-2 \mathrm{H}-2,90-92$ & 54 & 1 & 8 & 21 & 3 & 11 & 0 \\
\hline $856 \mathrm{~A}-1 \mathrm{H}-1,0-1$ & 44 & 8 & 8 & 15 & 5 & 13 & 1 \\
\hline $857 \mathrm{~A}-4 \mathrm{H}-3,64-66$ & 52 & 1 & 26 & 4 & 1 & 13 & 0 \\
\hline \multicolumn{8}{|l|}{ Cluster 2} \\
\hline $856 \mathrm{~A}-3 \mathrm{H}-5,78-80$ & 1 & 3 & 3 & 64 & 6 & 17 & 0 \\
\hline $857 \mathrm{~A}-5 \mathrm{H}-5,140-142$ & 0 & 5 & 3 & 61 & 8 & 14 & 3 \\
\hline $856 \mathrm{~A}-3 \mathrm{H}-5,130-132$ & 2 & 4 & 1 & 43 & 6 & 34 & 3 \\
\hline $857 \mathrm{~A}-5 \mathrm{H}-5,105-107$ & 1 & 7 & 1 & 39 & 12 & 31 & 4 \\
\hline $856 \mathrm{~A}-3 \mathrm{H}-5,74-76$ & 3 & 7 & 0 & 40 & 9 & 21 & 2 \\
\hline $856 \mathrm{~A}-3 \mathrm{H}-5,96-98$ & 1 & 4 & 2 & 48 & 7 & 20 & 1 \\
\hline \multicolumn{8}{|l|}{ Cluster $3 \mathrm{c}$} \\
\hline $857 \mathrm{~A}-1 \mathrm{H}-1,0-1$ & 16 & 3 & 8 & 19 & 3 & 50 & 0 \\
\hline $857 \mathrm{~A}-1 \mathrm{H}-3,10-13$ & 16 & 0 & 10 & 18 & 2 & 50 & 0 \\
\hline $856 \mathrm{~A}-1 \mathrm{H}-1.91-93$ & 14 & 0 & 3 & 21 & 3 & 53 & 0 \\
\hline $857 \mathrm{~A}-8 \mathrm{H}-7,22-26$ & 18 & 0 & 4 & 24 & 1 & 53 & 0 \\
\hline $857 \mathrm{~A}-1 \mathrm{H}-5,89-91$ & 16 & 0 & 8 & 20 & 8 & 41 & 0 \\
\hline $857 \mathrm{~A}-1 \mathrm{H}-1,79-81$ & 28 & 1 & 18 & 6 & 1 & 40 & 0 \\
\hline $857 \mathrm{~A}-\mathrm{IH}-2,125-129$ & 22 & 0 & 18 & 11 & 6 & 42 & 0 \\
\hline $857 \mathrm{~A}-7 \mathrm{H}-7,28-32$ & 33 & 1 & 4 & 11 & 1 & 35 & 0 \\
\hline $857 \mathrm{~A}-8 \mathrm{H}-3,54-58$ & 39 & 0 & 8 & 11 & 0 & 38 & 0 \\
\hline $857 \mathrm{~A}-8 \mathrm{H}-5,114-118$ & 29 & 0 & 7 & 15 & 1 & 46 & 0 \\
\hline $857 \mathrm{~A}-10 \mathrm{H}-1,124-127$ & 31 & 0 & 7 & 14 & 2 & 45 & 0 \\
\hline $857 \mathrm{~A}-10 \mathrm{H}-2,12-14$ & 30 & 0 & 8 & 13 & 0 & 48 & 0 \\
\hline $857 \mathrm{~A}-2 \mathrm{H}-7,26-28$ & 31 & 1 & 5 & 11 & 3 & 46 & 0 \\
\hline $857 \mathrm{~A}-1 \mathrm{H}-6,36-38$ & 27 & 0 & 5 & 18 & 4 & 42 & 0 \\
\hline
\end{tabular}

Table 8. Mean species composition (\%) and standard deviation of cluster assemblages.

\begin{tabular}{crcccccc}
\hline Cluster & Pdl & Pdr & Bul & Qui & Glu & Uvu & Tran \\
\hline lb & $68 \pm 7$ & $1 \pm 2$ & $4 \pm 4$ & $9 \pm 4$ & $2 \pm 2$ & $14 \pm 6$ & $0 \pm 1$ \\
1a & $51 \pm 5$ & $1 \pm 2$ & $6 \pm 7$ & $15 \pm 6$ & $1 \pm 1$ & $23 \pm 8$ & $0 \pm 0$ \\
2 & $1 \pm 1$ & $5 \pm 2$ & $2 \pm 1$ & $49 \pm 10$ & $8 \pm 2$ & $23 \pm 7$ & $2 \pm 1$ \\
3c & $26 \pm 7$ & $0 \pm 1$ & $7 \pm 5$ & $15 \pm 5$ & $2 \pm 2$ & $46 \pm 5$ & $0 \pm 0$ \\
3b & $31 \pm 8$ & $5 \pm 4$ & $14 \pm 5$ & $31 \pm 5$ & $3 \pm 1$ & $13 \pm 4$ & $1 \pm 2$ \\
3a & $28 \pm 8$ & $1 \pm 3$ & $11 \pm 6$ & $24 \pm 6$ & $3 \pm 2$ & $30 \pm 7$ & $0 \pm 1$
\end{tabular}

Notes: $\mathrm{Pdl}=$ sinistral Neogloboquadrina pachyderma, $\mathrm{Pdr}=$ dextral Neogloboquadrina pachyderma $; \mathrm{Bul}=$ Globigerina bulloides; Qui $=$ Turborotalita quinqueloba; $\mathrm{Glu}=$ Globigerinita glutinata Uvu = Globigerinita $u$ vula group; Tran $=$ Transitional $/ \mathrm{cool}$ subtropical species including Globorotalia hirsuta, Globorotalia inflata, Globigerinoides ruber, Globoturborotalita rubescens, Turborotalita humilis, Tenuitella iota, Orbulina universa.

\begin{tabular}{lcrrrrrr}
\hline \multicolumn{1}{c}{ Sample } & PdI & Pdr & Bul & Qui & Glu & Uvu & Tran \\
\hline 857A-8H-6, 52-56 & 27 & 0 & 5 & 18 & 2 & 46 & 0 \\
856A-5H-2, 6-8 & 39 & 0 & 0 & 16 & 0 & 45 & 0 \\
857A-8H-4, 43-47 & 24 & 0 & 5 & 11 & 1 & 56 & 0 \\
Cluster 3b & & & & & & & \\
857A-5H-4, 57-61 & 19 & 7 & 8 & 39 & 3 & 15 & 7 \\
857A-5H-4, 130-132 & 24 & 7 & 7 & 38 & 4 & 15 & 1 \\
857A-5H-4, 70-72 & 27 & 11 & 13 & 34 & 3 & 9 & 0 \\
856A-2H-5, 86-88 & 40 & 1 & 14 & 27 & 3 & 14 & 0 \\
857A-2H-2, 20-22 & 38 & 0 & 15 & 27 & 1 & 19 & 0 \\
857A-4H-4, 12-14 & 40 & 5 & 15 & 27 & 4 & 8 & 0 \\
857A-4H-4, 30-32 & 30 & 1 & 23 & 28 & 3 & 12 & 0
\end{tabular}

Cluster 3a

$857 \mathrm{~A}-6 \mathrm{H}-2,76-80$

$857 \mathrm{~A}-6 \mathrm{H}-3,27-31$

$856 \mathrm{~A}-5 \mathrm{H}-1,19-21$

$857 \mathrm{~A}-4 \mathrm{H}-4,38-40$

$857 \mathrm{~A}-6 \mathrm{H}-5,4-8$

$857 \mathrm{~A}-6 \mathrm{H}-4,66-70$

856A-3H-4, 91-93

$857 \mathrm{~A}-4 \mathrm{H}-5,127-129$

857 A-2H-4, 127-129

$857 \mathrm{~A}-6 \mathrm{H}-1,59-63$

$857 \mathrm{~A}-7 \mathrm{H}-4,1-5$

$857 \mathrm{~A}-7 \mathrm{H}-4,85-89$

857A-7H-3, 37-39

857A-5H-2, 13-17

856 A-3H-6, 92-94

$857 \mathrm{~A}-2 \mathrm{H}-4,98-100$

857A-9H-3, 74-80

$857 \mathrm{~A}-2 \mathrm{HI}, 45-48$

$857 \mathrm{~A}-2 \mathrm{H}-3,98-100$

$857 \mathrm{~A}-2 \mathrm{H}-5,7-9$

$857 \mathrm{~A}-7 \mathrm{H}-5,75-79$

857A-7H-6, 12I-125

856A-2H-4, 101-103

$856 \mathrm{~A}-2 \mathrm{H}-3,90-92$

$856 \mathrm{~A}-3 \mathrm{H}-3,72-74$

857A-2H-3, 129-131

857A-2H-2, 129-131

$857 \mathrm{~A}-10 \mathrm{H}-4,99-101$

857A-6H-7, 38-42

$856 \mathrm{~A}-1 \mathrm{H}-2,48-50$

$856 \mathrm{~A}-2 \mathrm{H}-7,56-58$

857A-2H-2, 96-98

$857 \mathrm{~A}-9 \mathrm{H}-5,79-84$

857A-4H-7, 43-47

856A-9H-6, 46-48

$857 \mathrm{~A}-4 \mathrm{H}-3,125-127$

856A-3H-4, 117-119

$857 \mathrm{~A}-4 \mathrm{H}-4,49-51$

$857 \mathrm{~A}-1 \mathrm{H}-4,72-76$

$\begin{array}{rrrrrrr}20 & 1 & 13 & 32 & 2 & 30 & 0 \\ 15 & 0 & 12 & 35 & 2 & 33 & 0 \\ 16 & 0 & 7 & 33 & 2 & 26 & 0 \\ 16 & 2 & 16 & 28 & 6 & 30 & 1 \\ 15 & 0 & 7 & 32 & 1 & 39 & 0 \\ 7 & 0 & 9 & 39 & 4 & 37 & 1 \\ 27 & 4 & 11 & 30 & 2 & 23 & 0 \\ 30 & 0 & 12 & 31 & 3 & 19 & 0 \\ 32 & 0 & 9 & 29 & 2 & 26 & 0 \\ 28 & 0 & 8 & 28 & 2 & 33 & 0 \\ 25 & 0 & 6 & 30 & 2 & 33 & 0 \\ 25 & 1 & 9 & 25 & 1 & 34 & 0 \\ 30 & 0 & 8 & 24 & 1 & 35 & 0 \\ 31 & 1 & 2 & 28 & 3 & 32 & 0 \\ 27 & 1 & 3 & 22 & 1 & 42 & 0 \\ 30 & 0 & 4 & 24 & 2 & 39 & 0 \\ 23 & 0 & 4 & 25 & 1 & 45 & 0 \\ 23 & 0 & 9 & 23 & 3 & 40 & 0 \\ 39 & 1 & 7 & 17 & 5 & 30 & 0 \\ 36 & 0 & 9 & 20 & 6 & 28 & 0 \\ 35 & 1 & 6 & 24 & 1 & 30 & 0 \\ 40 & 0 & 7 & 21 & 0 & 30 & 0 \\ 41 & 1 & 6 & 23 & 2 & 22 & 1 \\ 39 & 1 & 13 & 17 & 6 & 21 & 2 \\ 31 & 0 & 22 & 21 & 2 & 22 & 0 \\ 28 & 0 & 20 & 22 & 2 & 26 & 0 \\ 31 & 0 & 12 & 23 & 3 & 31 & 0 \\ 27 & 0 & 14 & 24 & 2 & 30 & 0 \\ 27 & 1 & 14 & 24 & 3 & 24 & 0 \\ 35 & 1 & 12 & 17 & 3 & 31 & 0 \\ 33 & 1 & 14 & 20 & 2 & 30 & 0 \\ 29 & 0 & 10 & 18 & 4 & 34 & 0 \\ 28 & 1 & 13 & 20 & 1 & 33 & 0 \\ 25 & 1 & 17 & 18 & 4 & 30 & 1 \\ 32 & 0 & 20 & 13 & 10 & 23 & 0 \\ 40 & 1 & 18 & 9 & 2 & 24 & 2 \\ 13 & 17 & 10 & 18 & 5 & 30 & 5 \\ 29 & 8 & 32 & 12 & 5 & 11 & 0 \\ 21 & 0 & 0 & 71 & 0 & 7 & 0\end{array}$

Notes: $\mathrm{Pdl}=$ sinistral Neogloboquadrina pachyderma $; \mathrm{Pdr}=$ dextral Neoglobo quadrina pachyderma; $\mathrm{Bul}=$ Globigerina bulloides; $\mathrm{Qui}=$ Turborotalita quinqueloba $;$ Glu = Globigerinita glutinata $;$ Uvu = Globigerinita uvula group: Tran = transitional $/ \mathrm{cool}$ subtropical species including Globorotalia hirsuta, Globorotalia inflata, Globigerinoides ruber, Globoturborotalita rubescens, Turborotalita humilis, Tenuitella iota, Orbulina universa.

work. Thanks also to the able and competent crew on board the Resolution and the excellent editorial staff at ODP. Ms. Susan Moffett prepared samples, maintained the sample database, and assisted in the microscopic analysis. Mr. Zhongbo Yu assisted in preparation of samples and completed the sample database. The onshore study was supported in part by a grant from the JOI/U.S. Science Support Program.

\section{REFERENCES}

Al-Aasm, I.S., and Blaise, B., 1991. Interaction between hemipelagic sediment and a hydrothermal system: Middle valley, northern Juan de Fuca ridge, subarctic northeast Pacific. Mar. Geol., 98:25-40.

Bandy, O.L., 1960. The geological significance of coiling ratios in the foraminifer Globigerina pachyderma (Ehrenberg). J. Paleontol., 34:671-681.

* Abbreviations for names of organizations and publications in ODP reference lists follow the style given in Chemical Abstracts Service Source Index (published by American Chemical Society). 
Berger, W.H., 1976. Biogenous deep-sea sediments: production, preservation, and interpretation. In Riley, J.P., and Chester, R. (Eds.), Chemical Oceanography (Vol. 5): San Diego (Academic Press), 266-389.

, 1981. Paleoceanography: the deep-sea record. In Emiliani, C. (Ed.), The Sea (Vol. 7): The Oceanic Lithosphere: New York (Wiley), 1437-1519.

Blow, W.H., 1959. Age, correlation, and biostratigraphy of the upper Tocuyo (San Lorenzo) and Pozón Formations, Eastern Falcón, Venezuela. Bull. Am. Paleontol., 39:67-251.

Bradshaw, J.S., 1959. Ecology of living planktonic foraminifera in the north and equatorial Pacific Ocean. Contrib. Cushman Found. Foraminiferal Res., 10:25-64.

Brady, H.B., 1882. Report on the Foraminifera. In Tizard and Murray (Eds.), Exploration of the Faröe Channel During the Summer of 1880, in Her Majesty's Hired Ship "Knight Errant." Proc, R. Soc. Edinburgh, 11:708717.

1884. Report on the Foraminifera dredged by H.M.S. Challenge during the years 1873-1876. Rep. Sci. Results Challenger Exped., Zool., 9:1-814.

Brönnimann, P., and Resig, J., 1971. A Neogene globigerinacean biochronologic time-scale of the Southwestern Pacific. In Winterer, E.L., Riedel, W.R., et al., Init. Repts. DSDP, 7 (Pt. 2): Washington (U.S. Govt. Printing Office), 1235-1469.

Brunner, C.A., and Ledbetter, M., 1987. Sedimentological and micropaleontological detection of turbidite muds in hemipelagic sequences: an example from the late Pleistocene levee of Monterey Fan, central California continental margin. Mar. Micropaleontol., 12:223-239.

1989. Late Quaternary quantitative planktonic foraminiferal biostratigraphy in turbidite sequences of the central California continental margin. Micropaleontology, 35:321-336.

Coulbourn, W.T., Parker, F.L., and Berger, W.H., 1980. Faunal and solution patterns of planktonic foraminifera in surface sediments of the North Pacific. Mar. Micropaleontol., 5:329-399.

Davis, E.E., Mottl, M.J., Fisher, A.T., et al., 1992. Proc. ODP, Init. Repts., 139: College Station, TX (Ocean Drilling Program).

d'Orbigny, A.D., 1826. Tableau méthodique de la classe des céphalopodes. Annales des Sciences Naturelles, Paris, Ser. 1, 7:245-314.

, 1839a. Foraminifères. In de la Sagra, R. (Ed.), Histoire Physique. Politique et Naturelle de L'île de Cuba: Paris (Arthus Bertrand), 8:1-224 [plates published separately].

1839b. Foraminiferes des iles Canaries. In Barker-Webb, P., and Berthelot, S. (Eds.), Historie Naturelle des Iles Canaries (Vol. 2): Paris (Béthune), 119-146.

Duncan, J.R., Fowler, G.A., and Kulm, L., 1970. Planktonic foraminiferalradiolarian ratios and Holocene-late Pleistocene deep sea stratigraphy off Oregon. Geol. Soc. Am. Bull., 81:561-566.

Egger, J.G., 1893. Foraminiferen aus Meeresgrundproben, gelothet von 1874 bis 1876 von S. M. Sch. Gazelle. Abh. Bayerischen Akad. Wiss., München, Math.-Physik. Cl., 18:193-458.

Ehrenberg, C.G., 1861. Elemente des tiefen Meeresgrundes im Mexikanischen Golfstrome bei Florida; über die Tiefgrund-Verhältnisse des Oceans am Eingange der Davisstrasse und bei Island. K. Preuss. Akad. Wiss. Berlin Monatsber., 275-315.

Favorite, F., Dodimead, A.J., and Nasu, K., 1976. Oceanography of the Subarctic Pacific Region, 1960-71. Internat. N. Pac. Fisheries Comm. Bull., 33:1-187.

Fleisher, R.L., 1974. Cenozoic planktonic foraminifera and biostratigraphy, Arabian Sea, Deep Sea Drilling Project, Leg 23A. In Whitmarsh, R.B. Weser, O.E., Ross, D.A., et al., Init. Repts. DSDP, 23: Washington (U.S. Govt. Printing Office), 1001-1072.

Gardner, J.V., Heusser, L.E., Quinterno, P., Stone, S.M., Barron, J.A., and Poore, R.Z., 1988. Clear Lake record vs. the adjacent marine record: a correlation of their past 20,000 years of paleoclimatic and paleoceanographic responses. In Sims, J.D. (Ed.), Late Quaternary Climate, Tectonism, and Sedimentation in Clear Lake, Northern California Coast Ranges. Spec. Pap.-Geol. Soc. Am., 214:171-182.

Hays, J.D., and Shackleton, N.J., 1976. Globally synchronous extinction of the radiolarian Stylatractus universus. Geology, 4:649-652.

Hemleben, C., Spindler, M., and Anderson, O.R., 1989. Modern Planktonic Foraminifera: New York (Springer-Verlag).

Hofker, J., 1956. Foraminifera of Santa Cruz and Thatch-Island, Virginia Archipelago, West Indies. Copenhagen Univ., Zool. Mus. Spolia (Skrifler), 15:234.

Ingle, J.C., Jr., 1973a. Neogene foraminifera from the northeastern Pacific Ocean, Leg 18, Deep Sea Drilling Project. In Kulm, L.D., von Huene, R., et al., Init. Repts. DSDP, 18: Washington (U.S. Govt. Printing Office), 517-567.

_ 1973b. Summary comments on Neogene biostratigraphy, physical stratigraphy, and paleo-oceanography in the marginal northeastern Pacific Ocean. In Kulm, L.D., von Huene, R., et al., Init. Repts. DSDP, 18: Washington (U.S. Govt. Printing Office), 949-960.

Karlin, R., and Lyle, M., 1986. Sediment studies of the Gorda Ridge. Final Report for Contract No. 63-630-8508, Oregon Department of Geology and Mineral Industries and the Gorda Ridge Technical Task Force, Open-File Rep., O-86-19.

Karlin, R., Lyle, M., and Zahn, R., 1992. Carbonate variations in the northeast Pacific during the late Quaternary. Paleoceanography, 7:43-61.

Keller, G., 1978. Morphologic variation of Neogloboquadrina pachyderma (Ehrenberg) in sediments of the marginal and central northeast Pacific Ocean and paleoclimatic interpretation. J. Foraminiferal Res., 8:208-224.

Kent, D., Opdyke, N.D., and Ewing, M., 1971. Climatic change in the North Pacific using ice-rafted detritus as a climatic indicator. Geol. Soc. Am. Bull., 82:2741-2754.

Kheradyar, T., 1992. Pleistocene planktonic foraminiferal assemblages and paleotemperature fluctuations in Japan Sea, Site 798. In Pisciotto, K.A., Ingle, J.C., Jr., von Breymann, M.T., Barron, J., et al., Proc. ODP, Sci. Results 127/128 (Pt. 1): College Station, TX (Ocean Drilling Program), 457-470.

Krumbein, W.C., and Pettijohn, F.J., 1938. Manual of Sedimentary Petrography: New York (Appleton-Century-Crofts).

Lagoe, M.B., and Thompson, P.R., 1988. Chronostratigraphic significance of late Cenozoic planktonic foraminifera from the Ventura Basin, California: potential for improving tectonic and depositional interpretation. J. Foraminiferal Res., 18:250-266.

Langer, M.R., 1992. Biosynthesis of glycosaminoglycans in foraminifera: a review. Mar. Micropaleontol., 19:245-255.

Lyle, M., Zahn, R., Prahl, F., Dymond, J., Collier, R., Pisias, N., and Suess, E., 1992. Paleoproductivity and carbon burial across the California Current: the Multitracers Transect, $42^{\circ} \mathrm{N}$. Paleoceanography, 7:251-272.

Moore, T.C., Jr., Burckle, L.H., Geitzenauer, K., Luz, B., Molina-Cruz, A., Robertson, J.H., Sachs, H., Sancetta, C., Thiede, J., Thompson, P., and Wenkam, C., 1980. The reconstruction of sea surface temperatures in the Pacific Ocean of 18,000 B.P. Mar. Micropaleontol., 5:215-247.

Natland, M.L., 1938. New species of Foraminifera from off the West Coast of North America and from the later Tertiary of the Los Angeles Basin. California Univ. Scripps Inst. Oceanogr. Bull. Tech. Ser., 4:137-164.

Nayudu, Y.R., 1964. Carbonate deposits and paleoclimatic implications in the northeast Pacific Ocean. Science, 146:515-517.

Nelson, C.H., Kulm, L.D., Carlson, P.R., and Duncan, J.R., 1968. Mazama Ash in the northeastern Pacific. Science, 161:47-49.

Olsson, R.K., and Goll, R., 1970. Biostratigraphy. In McManus, D.A., Burns, R.E., et al., Init. Repts. DSDP, 5: Washington (U.S. Govt. Printing Office), 557-567.

Parker, F.L., 1962. Planktonic foraminiferal species in Pacific sediments. Micropaleontology, 8:219-254.

Reynolds, L., and Thunell, R.C., 1985. Seasonal succession of planktonic foraminifera in the subpolar North Pacific. J. Foraminiferal Res., 15:282-301. 1986. Seasonal production and morphologic variation of Neogloboquadrina pachyderma (Ehrenberg) in the northeast Pacific. Micropaleontology, 32:1-18.

Rögl, F., and Bolli, H.M., 1973. Holocene to Pleistocene planktonic foraminifera of Leg 15, Site 147 (Cariaco Basin [Trench], Caribbean Sea) and their climatic interpretation. In Edgar, N.T., Saunders, J.B., et al., Init. Repts. DSDP, 15: Washington (U.S. Govt. Printing Office), 553-615.

Sancetta, C.A., 1979. Oceanography of the North Pacific during the last 18,000 years: evidence from fossil diatoms. Mar. Micropaleontol., 4:103-123.

Sautter, L.R., and Sancetta, C.A., 1992. Seasonal associations of phytoplankton and planktic foraminifera in an upwelling region and their contribution to the seafloor. Mar. Micropaleontol., 18:263-278.

Sautter, L.R., and Thunell, R.C., 1989. Seasonal succession of planktonic foraminifera: results from a four-year time-series sediment trap experiment in the northeast Pacific. J. Foraminiferal Res., 19:253-267.

, 1991. Planktonic foraminiferal response to upwelling and seasonal hydrographic conditions: sediment trap results from San Pedro Basin, Southern California Bight. J. Foraminiferal Res., 21:347-363.

Sidner, B.R., and McKee, T.R., 1976. Geochemical controls on vertical distribution of iron-rich agglutinated foraminifers in late Quaternary continental slope sediments from northwest Gulf of Mexico. AAPG Bull., 60:722-723.

Stow, D.A.V., and Piper, D.J.W., 1984. Fine-Grained Sediments: Deep-Water Processes and Facies: London (Blackwell Sci. Publ.). 


\section{C.A. BRUNNER}

Sverdrup, H.U., Johnson, M.W., and Fleming, R.H. (Eds.), 1942. The Oceans: Their Physics, Chemistry and General Biology: Englewood Cliffs, NJ (Prentice-Hall).

Thompson, P.R., 1980. Foraminifers from Deep Sea Drilling Project Sites 434, 435, and 436, Japan Trench. In von Huene, R., and Nasu, N., et al., Init. Repts. DSDP, 56, 57 (Pt. 2): Washington (U.S. Govt. Printing Office), 775-807.

1981. Planktonic foraminifera in the western North Pacific during the past 150,000 years: comparison of modern and fossil assemblages. Palaeogeogr., Palaeoclimatol., Palaeoecol., 35:241-279.

Thompson, P.R., and Shackleton, N.J., 1980. North Pacific paleoceanography: late Quaternary coiling variations of planktonic foraminifer Neogloboquadrina pachyderma. Nature, 287:829-833.
Zahn, R., Rushdi, A., Pisias, N.G., Bornhold, B.D., Blaise, B., and Karlin, R., 1991. Carbonate deposition and benthic del ${ }^{13} \mathrm{C}$ in the subarctic Pacific: implications for changes of the oceanic carbonate system during the past 750,000 years. Earth Planet. Sci. Lett., 103:116-132.

Date of initial receipt: 21 January 1993

Date of acceptance: 8 June 1993

Ms 139SR-206 
Table 9. Dendrogram of results of Q-mode cluster analysis.

\section{Euclidean Distance Coefficient}

Sample

$856 \mathrm{~A}-6 \mathrm{H}-6,46-48$

$856 \mathrm{~A}-6 \mathrm{H}-6,112-114$

$856 \mathrm{~A}-6 \mathrm{H}-3,127-129$

$856 \mathrm{~A}-7 \mathrm{H}-2,12-14$

$856 \mathrm{~A}-4 \mathrm{H}-7,62-64$

$856 \mathrm{~A}-5 \mathrm{H}-7,88-90$

$857 \mathrm{~A}-8 \mathrm{H}-5,40-44$

$856 \mathrm{~A}-4 \mathrm{H}-2,81-83$

$856 \mathrm{~A}-4 \mathrm{H}-3,122-124$

$856 \mathrm{~A}-4 \mathrm{H}-4,88-90$

$856 \mathrm{~A}-2 \mathrm{H}-6,86-88$

$857 \mathrm{~A}-2 \mathrm{H}-5,22-24$

$856 \mathrm{~A}-4 \mathrm{H}-1,82-84$

857A-5H-4, 9-13

857A-2H-1, 105-107

857A-4H-5, 40-44

$857 \mathrm{~A}-4 \mathrm{H}-4,70-74$

$857 \mathrm{~A}-8 \mathrm{H}-1,119-123$

856A-4H-6, 108-110

$856 \mathrm{~A}-6 \mathrm{H}-2,123-125$

$856 \mathrm{~A}-4 \mathrm{H}-5,96-98$

856A-5H-3, 135-137

856A-6H-1, 68-70

$856 A-5 H-5,133-135$

856A-7H-1, 48-50

857A-2H-1, 97-99

857A-2H-6, 9-11

857A-2H-4, 12-14

$856 \mathrm{~A}-5 \mathrm{H}-4,88-90$

857A-8H-2, 21-25

857A-9H-4, 60-63

$856 \mathrm{~A}-2 \mathrm{H}-2,90-92$

856A-1H-1, 0-1

857A-4H-3, 64-66

$856 \mathrm{~A}-3 \mathrm{H}-5,78-80$

$857 A-5 H-5,140-142$

$856 \mathrm{~A}-3 \mathrm{H}-5,130-132$

857A-5H-5, 105-107

$856 \mathrm{~A}-3 \mathrm{H}-5,74-76$

856A-3H-5, 96-98

$857 \mathrm{~A}-1 \mathrm{H}-1, \quad 0-1$

857A-1H-3, 10-13

856A-1H-1, 91-93

$857 \mathrm{~A}-8 \mathrm{H}-7,22-26$

$857 \mathrm{~A}-1 \mathrm{H}-5,89-91$

857A-1H-1, 79-81

857A-1H-2, 125-129

857A-7H-7, 28-32

$857 \mathrm{~A}-8 \mathrm{H}-3,54-58$

857A-8H-5, 114-118

857A- $10 \mathrm{H}-1,124-127101$

857A-10H-2, 12-14 102

$857 \mathrm{~A}-2 \mathrm{H}-7,26-28$

$857 A-1 H-6,36-38$

$857 \mathrm{~A}-8 \mathrm{H}-6,52-56$

$856 \mathrm{~A}-5 \mathrm{H}-2, \quad 6-8$

$857 \mathrm{~A}-8 \mathrm{H}-4,43-47$

857A-5H-4, 57-61

$857 \mathrm{~A}-5 \mathrm{H}-4,130-132$

$857 \mathrm{~A}-5 \mathrm{H}-4,70-72$

$856 \mathrm{~A}-2 \mathrm{H}-5,86-88$

$857 \mathrm{~A}-2 \mathrm{H}-2,20-22$

$857 \mathrm{~A}-4 \mathrm{H}-4,12-14$

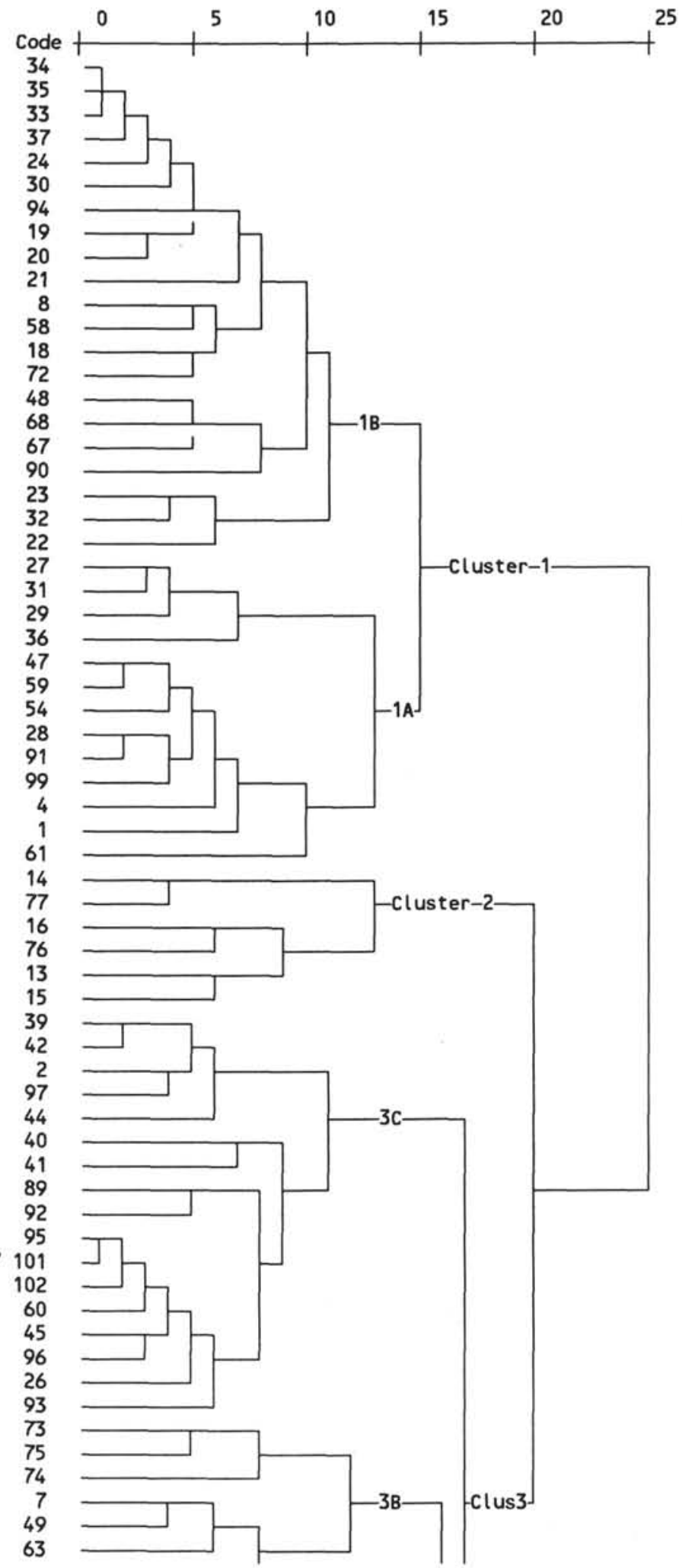


Table 9 (continued).
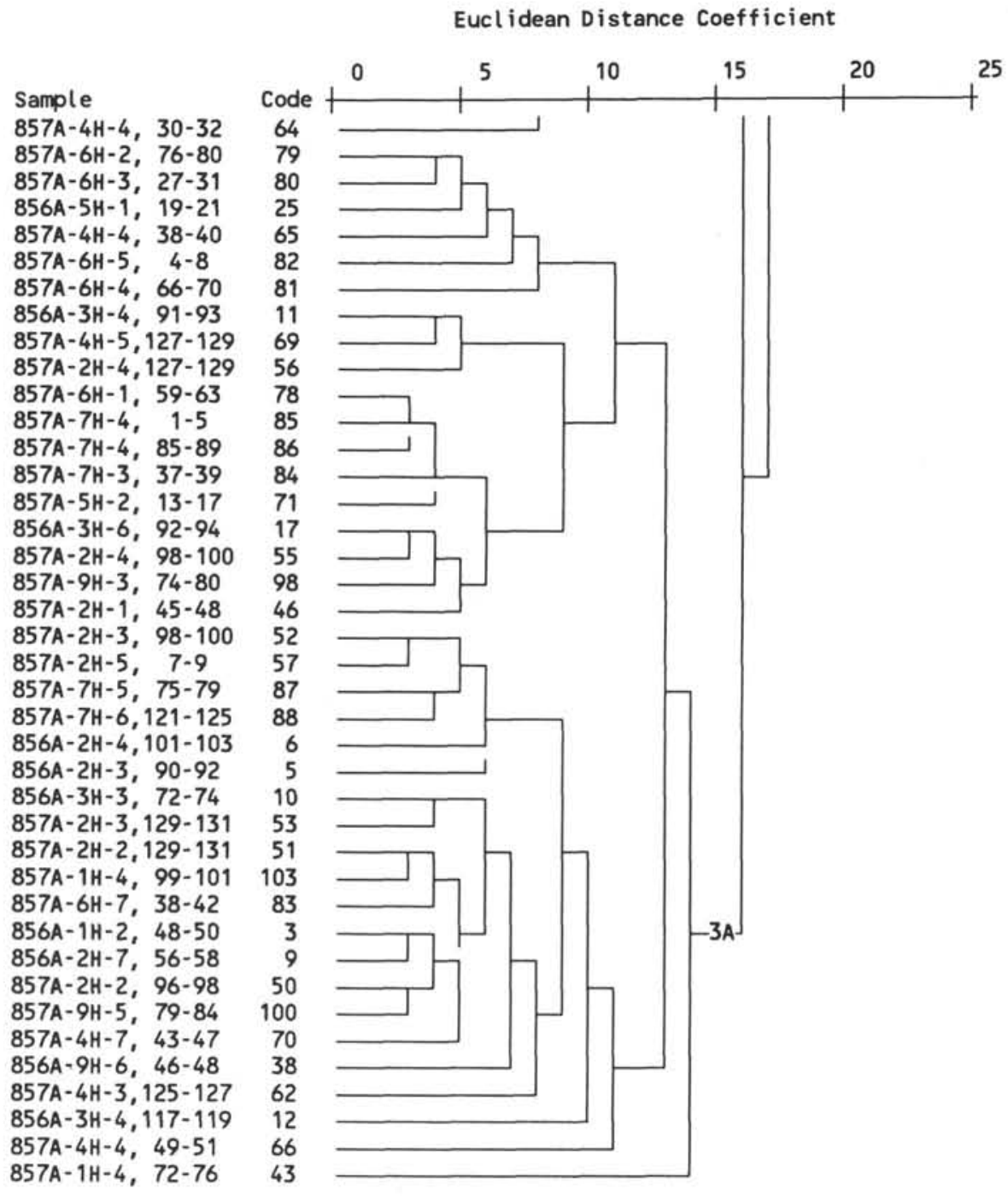

Table 10. Correlation analysis, matrix of correlation coefficients.

\begin{tabular}{|c|c|c|c|c|c|c|c|}
\hline $\begin{array}{l}\text { Correlation } \\
\text { Matrix }\end{array}$ & $\begin{array}{l}\text { Sinistral } \mathrm{Nq} \text {. } \\
\text { pachyderma }\end{array}$ & $\begin{array}{l}\text { Dextral } \mathrm{Nq} \text {. } \\
\text { pachyderma }\end{array}$ & $\begin{array}{c}\text { Ga. } \\
\text { bulloides }\end{array}$ & $\begin{array}{c}\mathrm{Tr} . \\
\text { quinqueloba }\end{array}$ & $\underset{\text { glutinata }}{G t .}$ & $\begin{array}{c}\text { Gt. } \\
\text { uvula }\end{array}$ & $\begin{array}{c}\text { Transitional } \\
\text { spp. }\end{array}$ \\
\hline Sinistral $\mathrm{Nq}$. pachyderma & 1.00 & & & & & & \\
\hline Dextral Nq. pachyderma & -0.20 & 1.00 & & & & & \\
\hline Ga, bulloides & -0.22 & 0.03 & 1.00 & & & & \\
\hline Tr. quinqueloba & $-0.72^{\circ}$ & 0.23 & -0.05 & 1.00 & & & \\
\hline Gt. glutinata & $-0.48^{*}$ & $0.43^{*}$ & 0.16 & $0.38^{\circ}$ & 1.00 & & \\
\hline Gt. uvula & $-0.52^{*}$ & $-0.031^{*}$ & -0.10 & -0.04 & -0.07 & 1.00 & \\
\hline Transitional spp. & -0.26 & $0.59^{*}$ & -0.09 & 0.27 & $0.40^{*}$ & -0.13 & 1.00 \\
\hline
\end{tabular}

Notes: ${ }^{*}=$ one-tailed significance of 0.001 : number of cases $=103$.

Table 11. Sedimentation rates based on tentative correlations.

\begin{tabular}{|c|c|c|c|c|c|c|}
\hline \multirow[b]{2}{*}{$\begin{array}{l}\text { Coiling } \\
\text { direction } \\
\text { zone }\end{array}$} & \multicolumn{3}{|c|}{ Hole $856 \mathrm{~A}$} & \multicolumn{3}{|c|}{ Hole 857A } \\
\hline & $\begin{array}{l}\text { Depth } \\
\text { of base } \\
\text { (mbsf) }\end{array}$ & $\begin{array}{c}\text { Tentative } \\
\text { age } \\
(\mathrm{yr})\end{array}$ & $\begin{array}{c}\text { Sed. } \\
\text { rate } \\
\left(\mathrm{cm} / 10^{3} \mathrm{yr}\right)\end{array}$ & $\begin{array}{l}\text { Depth } \\
\text { of base } \\
\text { (mbsf) }\end{array}$ & $\begin{array}{c}\text { Tentative } \\
\text { age } \\
(\mathrm{yr})\end{array}$ & $\begin{array}{c}\text { Sed. rate } \\
\left(\mathrm{cm} / 10^{3} \mathrm{yr}\right)\end{array}$ \\
\hline CD1 & $0.46 \pm 0.46 \mathrm{~m}$ & 11,000 & 4 & $2.31 \pm 0.40 \mathrm{~m}$ & 11,000 & 21 \\
\hline Unzoned & - & - & - & $26.94 \pm 0.05 \mathrm{~m}$ & $?$ & $?$ \\
\hline CD3 & $20.06 \pm 0.56 \mathrm{~m}$ & 125,000 & 17 & $40.37 \pm 0.21 \mathrm{~m}$ & 125,000 & 33 \\
\hline
\end{tabular}

